Portland State University

PDXScholar

\title{
Total Mercury in Stranded Marine Mammals from the Oregon and Southern Washington Coasts
}

\author{
Nathan J. Wintle \\ Portland State University
}

Follow this and additional works at: https://pdxscholar.library.pdx.edu/open_access_etds

Part of the Life Sciences Commons

Let us know how access to this document benefits you.

\section{Recommended Citation}

Wintle, Nathan J., "Total Mercury in Stranded Marine Mammals from the Oregon and Southern Washington Coasts" (2011). Dissertations and Theses. Paper 310.

https://doi.org/10.15760/etd.310

This Thesis is brought to you for free and open access. It has been accepted for inclusion in Dissertations and Theses by an authorized administrator of PDXScholar. Please contact us if we can make this document more accessible: pdxscholar@pdx.edu. 
Total Mercury in Stranded Marine Mammals from the Oregon and Southern Washington Coasts

by

Nathan J.P. Wintle

A thesis submitted in partial fulfillment of the requirements for the degree of

Master of Science

in

Biology

Thesis Committee:

Deborah A. Duffield, Chair

Ronald D. Jones

Mandy L.H. Cook

Portland State University

2011 
ABSTRACT

Muscle samples from 105 marine mammals stranded along the Oregon-Washington coasts (2002-2009) were tested for levels of total mercury by Cold Vapor Atomic Fluorescence Spectrometry. The total mercury present is predominantly in the form of highly toxic methylmercury. After normalizing muscle tissue to $75 \%$ water weight, due to variance in water content, Steller sea lions (Eumetopias jubatus) and northern elephant seals (Mirounga angustirostris) exhibited the highest mean concentrations of total mercury followed by harbor seals (Phoca vitulina), harbor porpoises (Phocoena phocoena), and California sea lions (Zalophus californianus); $0.34 \pm 0.278,0.34 \pm 0.485,0.21 \pm 0.216,0.17 \pm$ 0.169 and $0.15 \pm 0.126 \mathrm{mg} / \mathrm{kg}$ normalized weight, respectively. Mean normalized values demonstrated limited muscle methylmercury accumulation in these species in the Pacific Northwest. Normalizing muscle mercury concentrations eliminated variability from desiccation, and allowed for a clearer indication of the amount of mercury the animal accumulated before stranding. However, actual wet weight concentrations in some of the stranded carcasses were high enough to pose a risk to scavengers. 


\section{ACKNOWLEDGMENTS}

I would like to thank everyone for his or her guidance in support of my project. I owe a large debt of gratitude to Stan Hillman and Ronald Jones for their extensive expertise, lab space, equipment, and friendship throughout the length of my research. For supplies and tools at a moment's notice, I'd like to thank Brad Buckley and Jason Podrabsky. Guidance in operating the CVAFS was provided by Dr. Liu and his lab at Florida International University. All of this would not have been possible if I did not have the support of my wonderful advisor, Deborah Duffield. 


\section{TABLE OF CONTENTS}

Abstract.......................................................... i

Acknowledgements..............................................ii

List of Tables..................................................

List of Figures....................................................

Glossary...................................................... vi

Chapter $1 \quad$ Introduction........................................

Chapter 2 Marine Mammal Science Journal Publication...............19

Chapter $3 \quad$ Discussion........................................ 35

Literature Cited ...................................................45

Appendix A Stranding Data for all 105 Samples......................54

Appendix B THg Concentrations of 105 Muscle Samples...............57

Appendix C Box and Whisker Plots............................6 60

Appendix D Log Transformed THg Concentrations.................62

Appendix E Species Linear Regression...........................63

Appendix F Tukey HSD Analysis of Health Code vs. [THg]............66

Appendix G Step-by-Step Mercury Analysis Procedure...............67 


\section{LIST OF TABLES}

Table 2.1- $\quad \mathrm{THg} \mathrm{mg} / \mathrm{kg}$ mean \pm S.D., median. w.w.= wet weight, d.w. $=$ dry weight, and normalized $=$ calculated wet weight value corrected to $75 \% \mathrm{H}_{2} \mathrm{O}$ of muscle samples from Steller sea lions $(E j)$, elephant seals $(M a)$, harbor seals $(P v)$, harbor porpoises $(P p)$, and California sea lions $(Z c)$ stranded from the Oregon and southern Washington coasts.................................28

Table 2.2- $\quad$ Species cohorts normalized THg $\mathrm{mg} / \mathrm{kg}$ mean \pm S.D. and range. $\mathrm{n}=$ cohort size.

Table 2.3- Previous studies of mercury in muscle tissue by species and region................................30

Table 3.1- Percent water weight \pm S.D., range in parenthesis. The variation in $\% \mathrm{H}_{2} \mathrm{O}$ could be due to a large number of factors including: sickness at stranding, time dead on beach or time in storage..........................38

Table 3.2- The results of the regression analysis. A significant value is indicated by bold values. All three methods for reporting mercury concentrations were analyzed for significance between $\mathrm{THg}$ and the age of the animal. Significance level of $0.05 \ldots \ldots \ldots \ldots \ldots \ldots . . . .43$ 


\section{LIST OF FIGURES}

Figure 1.1- The percentage of methylmercury is inversely related to the amount of inorganic and elemental mercury in tissue...........................................9

Figure 2.1- Locations of strandings sampled from Oregon and Washington, 2002-2009. Value next to city name indicates number of individual strandings sampled...23 


\section{GLOSSARY}

\begin{tabular}{|c|c|}
\hline $\begin{array}{l}\text { CSL } \\
\text { df } \\
d w\end{array}$ & $\begin{array}{l}\text { California sea lion } \\
\text { degrees of freedom } \\
\text { dry weight }\end{array}$ \\
\hline $\mathrm{Ej}$ & Eumetopias jubatus, Steller sea lion \\
\hline EPA & Environmental Protection Agency \\
\hline $\mathrm{f}$ & female \\
\hline fw & fresh weight \\
\hline GI & gastro-intestinal \\
\hline $\mathrm{Hg}$ & mercury \\
\hline $\mathrm{m}$ & male \\
\hline Ma & Mirounga angustirostris, northern elephant seal \\
\hline $\mathrm{MeHg}$ & methylmercury \\
\hline $\mathrm{n}$ & sample size \\
\hline $\mathrm{nm}$ & nanometer \\
\hline norm. & normalized to $75 \%$ water weight \\
\hline NOSWSN & Northern Oregon Southern Washington Stranding Network \\
\hline NPL & National Priorities List \\
\hline OR & Oregon \\
\hline $\mathrm{p}$ & significance \\
\hline $\mathrm{Pp}$ & Phocoena phocoena, harbor porpoise \\
\hline ppm & parts per million; $\mathrm{mg} / \mathrm{kg}$ \\
\hline $\mathrm{ppb}$ & parts per billion; $\mathrm{ug} / \mathrm{kg}$ \\
\hline ppt & parts per trillion; $\mathrm{ng} / \mathrm{kg}$ \\
\hline $\mathrm{Pv}$ & Phoca vitulina, harbor seal \\
\hline S.D. & standard deviation \\
\hline S.P. & scatter plot \\
\hline S.W. & Shapiro-Wilk \\
\hline $\mathrm{THg}$ & total mercury \\
\hline WA & Washington \\
\hline wW & wet weight \\
\hline $\mathrm{Zc}$ & Zalophus californianus, California sea lion \\
\hline O & female \\
\hline$\square$ & male \\
\hline$\triangle$ & unknown \\
\hline
\end{tabular}




\section{Chapter 1}

\section{Introduction}

\subsection{Project Rationale-}

Mercury has recently gained recognition as a chemical of concern by the U.S. Environmental Protection Agency and the U.S. Food and Drug Administration (Gerstenberger et al., 2009), partially due to advances in detection methods, but also from growing health concerns associated with heavy metal pollution. All across the United States, fish advisories have been put in place to notify consumers of the potential hazards of mercury in fish (U.S. EPA, 2001).

The last reported study of mercury in marine mammals from the Oregon coast is over thirty years old (Buhler et al., 1974). This represents a serious gap in the knowledge of contaminants that are becoming increasingly common in federally protected marine mammals (U.S. EPA, 2001). Several marine mammal feeding and breeding areas are found on the Oregon and Washington coasts. Some species are here year round such as Steller sea lions (Eumatopias jubatus) and harbor seals (Phoca vitulina) (Merrick et al., 1995; Pearson and Verts, 1970). Other marine mammals migrate into these waters seasonally, such as California sea lions (Zalophus californianus) northern elephant seals (Mirounga angustirostris) and to a more restricted extent harbor porpoises (Phocoena phocoena) (Calambokidis and Barlow, 1991; Reeves et al., 2002). 
Multiple advisories on mercury levels in fish have been put in place in Oregon (U.S. EPA, 2001), intended to limit human consumption of these fish. This raises questions about mercury accumulation in marine mammals whose diets are predominantly fish based. Humans limited to a few fish a month risk suffering neurological effects when mercury levels approach the parts-per-million range (Eisler, 2006; U.S. EPA, 2001). This could have dire consequences for marine mammals that primarily feed on fish from the same mercury-listed stocks. For humans, the Environmental Protection Agency has set a consumption advisory level at $0.5 \mathrm{ppm}$ of mercury in fish; in contrast, the Food and Drug Association's consumption advisory level is $1.0 \mathrm{ppm}$ within fish (Gerstenberger et al., 2009), only further confusing individuals on which concentrations represent a health concern.

\subsection{Mercury Sources}

Mercury is distributed throughout the environment by both natural and anthropogenic activities (Eisler, 2006). Although Oregon does not have any significant point-source mercury pollution along the coast, there are several non-point source inputs from the burning of fossil fuels, volcanism, and historic mining operations (Manning, 2009; Park and Curtis, 1997; Nriagu and Becker, 2003; Sethejintanin et al., 2004; Tunnicliffe et al., 1996). In general, the largest contributor to mercury in the atmosphere comes from the burning of fossil fuels such as coal (Pacyna and Pacyna, 2002). Nearly 90\% of the 
mercury in the United States comes from solid waste incineration and fossil fuel combustion (Tang et al., 2007). China, which brings a new coal burning power plant online each week, contributes $56 \%$ of the total global amount of mercury each year (Porcella, 1994).

Other less prominent sources of mercury include mining and cement production facilities. South of Eugene, OR, is the Black Butte Mine that is listed as an EPA Superfund site (Manning, 2009). The Black Butte Mine operated as a gold mine until the late 1960's. Gold was amalgamated with mercury, leaving mercury waste in large piles of mine tailings. This method of extracting gold was widely used before the consequences of mercury poisoning were known and understood. With building-sized piles of contaminated tailings, rain and erosion continually wash the mercury into surrounding streams, which then works its way to larger bodies of water such as the Willamette and the Columbia Rivers, entering the food chain in the process (Chasar et al., 2009). Mercury is also released into the Willamette and Columbia Rivers from industrial activities along their banks, including the two dozen pulp and paper mills, two chlor-alkali production facilities, and various chemical manufacturing plants (Eisler, 1984).

Mercury also comes from volcanic eruptions. Fallout from the eruption of Mt. St. Helens in 1980 spewed nearly 100 tons of mercury into the surrounding area, as well as across the nation (Nriagu and Becker, 2003). In volcanic eruptions, mercury is released in two phases; first in the initial 
eruption and second in the degassing period where the eruption is cooling, but still releasing gas. Ultimately, the released mercury enters waterways and finds its way into the food chain.

Hydrothermal vents are similar to volcanic eruptions. Tectonic activity from the sliding and grinding of the Pacific, North American, and Juan de Fuca plates cause hydrothermal vents off the coast of Oregon, Washington, and Alaska to release mercury several thousand feet underwater (Lamborg et al., 2006). The fluids coming from hydrothermal vents on the Gorda Ridge contain an extremely elevated amount of mercury (5.8-17.3 ppm), when compared to the ambient mercury concentration of seawater (2-4 parts-per-trillion, ppt) (Lamborg et al., 2006). Furthermore, it has been suggested that the Gorda Ridge could produce up to $4.0 \%$ of the total annual mercury inputs into the ocean (10-16.4 Mmole/year), (Lamborg et al., 2006). The primary form of mercury released from hydrothermal vents is methylmercury, which settles in ocean sediments and is incorporated into benthic fauna (Lamborg et al., 2006). Mercury is then concentrated by biomagnification, ending up in top predators such as marine mammals.

\subsection{Mercury Transport \& Speciation}

Mercury is found in the environment in three forms: elemental, inorganic, and organic. Elemental mercury exists as mercury gas and metallic mercury $\left(\mathrm{Hg}^{0}\right)$, which is the form commonly used in dental amalgamations. 
Mercury has two valence electrons, allowing it to easily volatize, becoming mercuric mercury $\left(\mathrm{Hg}^{2+}\right)$ (Akagi and Nishimura, 1991). Mercuric mercury has a strong positive charge and in the atmosphere attracts negatively charged elements such as chlorine and sulfur (Morel et al., 1998). $\mathrm{Hg}^{2+}$ bonds to form inorganic mercuric chloride $\left(\mathrm{HgCl}_{2}\right)$ and inorganic mercury sulfide, commonly called cinnabar $(\mathrm{HgS})$. As inorganic mercury is formed in the atmosphere, it loses its volatility and deposits back in to soils and waterways (Morel et al., 1998). In soils, lakes, streams, and oceans, sulfur-reducing bacteria use inorganic mercury for energy by cleaving the ionic bond between mercury and sulfur or chlorine (Jackson, 1998). Sulfur-reducing bacteria have vitamin $\mathrm{B}_{12}$ or cobalamin (Eisler, 2006), an organic compound with methyl groups, that replace the cleaved sulfur or chlorine ions to form organic mercury $\left(\mathrm{CH}_{3} \mathrm{Hg}^{+}\right)$. Once mercury is converted into its organic form, it rapidly bioaccumulates (Eisler, 1984). Since methylmercury is not easily broken down and is not excreted from its host (Elhassani, 1983), it can concentrate in top predators to several magnitudes. Predators at the top of the food chain, such as marine mammals, bioaccumulate methylmercury $1: 1 \times 10^{6}$ times greater than the dissolved mercury concentrations of the surrounding waters (U.S. EPA, 2001).

Mercury has no known metabolic function (Eisler, 2006). Forms of mercury that have low toxicity, such as inorganic mercury, can be transformed into forms with very high toxicity, such as methylmercury. Methylmercury is five 
times more soluble than inorganic mercury (Goyer, 1986). Ninety to ninetyfive percent of ingested methylmercury is absorbed in the GI tract compared with $15 \%$ of inorganic mercury (Goyer, 1986; Eisler, 2006).

Mercury acts as a mutagen, carcinogen, and teratogen causing genetic, histopathological, and embryological effects (Satoh, 1995). Methylmercury is the most toxicologically significant mercury species because it is produced naturally from inorganic mercury by microbial activity and is lipid soluble, allowing for easy transport across alveolar surfaces, as well as the blood-brain and placental barriers (Satoh, 1995). Ingestion is the main route of uptake for methylmercury and the primary target organs are the brain and neurological tissues. It specifically causes necrosis of the granule cell layer of the cerebellum, and is also associated with kidney disorders (Norton et al., 1986). Sensory nerve fibers can be damaged, and membrane permeability of those cells increases upon mercury poisoning (Eisler, 2006). In the central nervous system, lesions developing in nervous tissue with degeneration of primary sensory ganglion cells (Roizin et al., 1977) cause the effects of Mad Hatters Syndrome, the type of mercury poisoning found in felt hat makers (Norton et al., 1986) and popularized by the movie Alice in Wonderland.

\subsection{Mercury Analysis}

As mercury has come under greater scrutiny in the last decade, analytical methods have improved, allowing rapid, inexpensive and more 
accurate detection results. Mercury is now being detected in the parts-pertrillion (ppt) range for background levels usually found in drinking water. Using older methods that were based on atomic absorption, which measures the proportion of photons absorbed, does not allow such low detection limits or accuracy (Van Delft and Vos, 1988). The development of atomic fluorescence, which measures the proportion of photons emitted from mercury, has been responsible for the increase of sensitivity and accuracy of mercury detection (Jones et al., 1997). In addition to detection sensitivity, previous methods for mercury detection in tissues used an open vessel digestion technique as well as cold vapor atomic absorption spectrometry. This open digestion allowed for a considerable loss of mercury to the surrounding air (Van Delft and Vos, 1988). Detection was improved by coupling a closed vessel technique with atomic fluorescence spectrometry. Detection limits went from 0.06 parts-per-billion (ppb) to 0.003 parts-pertrillion (ppt) (Szakacs, 1980). The closed vessel technique allows for rapid and cost effective analysis of multiple samples for total mercury and measures the sum total of all mercury species in a given sample (Jones et al., 1997).

\subsection{Mercury in Marine Mammals}

In pinnipeds (sea lions and seals), the highest reported concentrations of mercury are found in their muscle, brain, blubber, kidney and liver tissues (Eisler, 2006). Mercury concentrations are especially pronounced in the liver 
due to selenium complexation (Smith and Armstrong, 1978); therefore, total mercury concentrations are usually highest in livers of marine mammals, lower in muscle, and lowest in blubber (Brookens et al., 2008). Methylmercury does not break down in the body and deposits in vascular tissues such as muscle (Goyer, 1986). Muscle, unlike liver or blubber, does not metabolize methylmercury and it can concentrate to significant levels (Gaskin et al., 1972; Holden, 1975; Harms et al., 1978; Smith and Armstrong, 1978; Eisler 1984). Methylmercury in muscle tissue also concentrates with age.

Unlike muscle tissue, the liver has a low concentration of methylmercury, but a high concentration of other mercury species such as inorganic and elemental mercury. The liver as well as the kidney have multiple protective mechanisms against high concentrations of mercury, including metallothioneins and selenium. They are, therefore, unreliable indicators of toxicity (Goyer, 1986), while mercury in muscle tissue is 90$100 \%$ methylmercury primarily bound to muscle proteins (Buhler et al., 1975). In general, the percentage of methylmercury is inversely correlated with total mercury content (Buhler et al., 1975); (Fig. 1). If methylmercury is high, other mercury species such as inorganic and elemental mercury are low (as in muscle) or if inorganic and elemental mercury are high, methylmercury is low (as in liver). 
Figure 1.1- The percentage of methylmercury is inversely related to the amount of inorganic and elemental mercury in tissue.

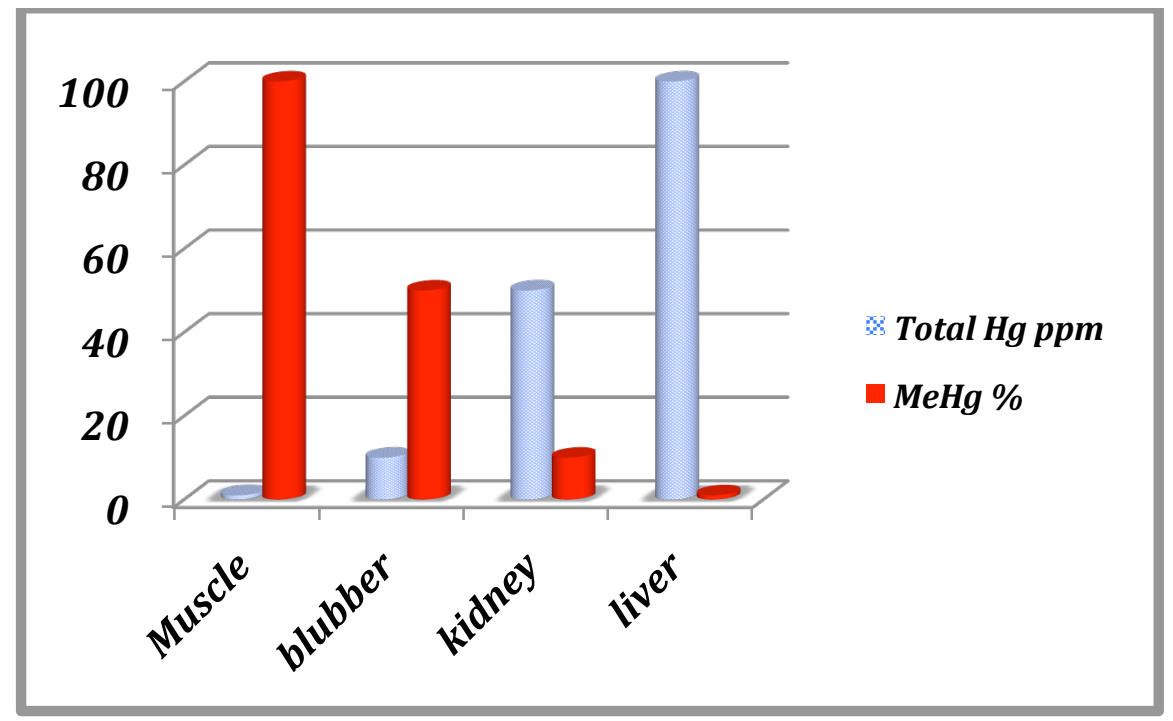

Marine mammals feed on a wide variety of prey, and thus, show varying levels of mercury accumulation (Reeves et al., 2002). Species that feed on large fish and cephalopods contained up to ten times as much mercury as species that feed on small fish and crustaceans (Harms et al., 1978). The accumulation of mercury has been shown to increase with age, reaching a plateau at 20 to 25 years of age in striped dolphins (Stenella coeruleoalba) (Itano et al., 1984). Increased mercury concentrations have also been related to poor health due to diseases, such as leptospirosis, and to proximity to urban areas (Buhler et al., 1975). Off the coast of Oregon and Washington increased mercury exposure comes from volcanic activity in the Juan De Fuca and Gorda Ridges (Lamborg et al., 2006). China’s increased use of coal burning power plants is also a main contributor to the overall amount of mercury that deposits on the west coast of the United States (Tang et al., 2007), primarily 
related to powerful trade winds (Kleypas and Yates, 2009). Superfund sites and industrial activities drain into major rivers such as the Columbia River and pollute coastal waters. Marine mammals feeding in these waterways act as environmental sentinels by bioaccumulating mercury. Because the last published mercury study was done in 1974 and was performed only on one species, it was important to look again at marine mammal mercury concentrations from Oregon.

\subsection{Study Species}

The Northern Oregon/Southern Washington Stranding Network (NOSWSN) has consistently collected data from marine mammal strandings since 1981. To evaluate mercury levels in these marine mammals, 105 muscle tissue samples were collected from the five most common strandings: Steller sea lions (Eumetopias jubatus, $\mathrm{n}=27$ ), California sea lions (Zalophus californianus, $\mathrm{n}=31$ ), northern elephant seals (Mirounga angustirostis, $\mathrm{n}=8$ ), harbor seals (Phoca vitulina, $\mathrm{n}=18$ ), and harbor porpoises (Phocoena phocoena, $\mathrm{n}=21)($ see Appendix A).

\section{Steller Sea Lions (Eumetopias jubatus)}

Steller sea lions are the largest of the eared seals or Otariids. They are sexually dimorphic, with males reaching over a ton, and females reaching about half that, around 700 pounds (Reeves et al., 2002). The coloration of 
Steller sea lions is often light brown to dark brown ventrally. They have a very large body and head with a blunt snout. Pups are born with a dark pelage, and molt around four months of age to a lighter brown color.

Steller sea lions, also known as northern sea lions, inhabit the waters of the northern Pacific Ocean from California to the sea of Okhotsk, north of Japan. They are most abundant in the Gulf of Alaska and British Columbia (Le Boeuf et al., 2007). Historically, Steller sea lions bred off of the Channel Islands in southern California, but they have not been seen there since the early 1980's (Fiscus and Baines, 1996).

In Oregon, Steller sea lions are found in breeding colonies on the Rogue and Orford Reefs, and they haul out consistently from Haceta Head to Astoria, feeding throughout Oregon waters. Females and males breed from late May until early July, giving birth to new pups a year later (Dempsey, 2010; Pitcher et al., 2007). Steller sea lions strand on the Oregon/So.

Washington coast throughout the year. Males will also swim up the Columbia River to the Bonneville Dam, taking advantage of local food sources such as salmon, steelhead, and sturgeon (Wright et al., 2007). In the ocean, their main food source comes from walleye, herring, rockfish, cod, squid and octopus (Reeves et al., 2002); all species that can be influenced by hydrothermal activity along the Oregon coast.

Of the three individual stocks: Western Pacific, Northeastern Pacific and Oregon, the Northeastern Pacific Steller sea lion stock has been declining 
over the past 30 years (Pitcher et al., 2007). The eastern stock of Steller sea lions is listed as a threatened species by the Endangered Species Act (Reeves et al., 2002). Although, the cause is still uncertain, there is much speculation that pollution and over-fishing are the main drivers. It is estimated that the Oregon population of Steller sea lions is increasing every year with a current population of over 2000 animals (Oregon Sea Grant, 2003).

\section{California Sea Lions (Zalophus californianus)}

Another large otariid, California sea lions are dark brown to black, with females and juveniles light brown to yellowish. Adult males are easily distinguishable by their large sagittal crest. Female and juvenile California sea lions have a slender body, in contrast to adult males, which are large and robust throughout their entire body to their hind quarters, which is slender. The snout is long and straight. Pups molt at about five months in age to a light gray pelage (Reeves et al., 2002). California sea lions are sexually dimorphic, with males reaching over 800 pounds and females usually only growing to around 200 pounds (Fiscus and Baines, 1966).

California sea lions breed off the southern California coast on the Channel Islands, and on more southern islands. Though their foraging range extends from the tip of Baja all of the way to Alaska, typically only males migrate into the northern waters, including Oregon and Washington (Reeves et al., 2002). They have a breeding season that is very similar to the Steller 
sea lion, typically forming rookeries from late May to early July (Fiscus and Baines, 1996). In the Pacific Northwest, their diet consists of anchovy, squid, sardines, mackerel and rockfish (Reeves et al., 2002). In Oregon they have been seen opportunistically taking fish such as salmon and steelhead in the Columbia River up to the Bonneville Dam and in the Willamette River at the Willamette Falls (Wright et al., 2007). These animals swim through and feed near major industrial centers and known mercury contaminated sites as well as in coastal waters (Sethajintanin, 2004).

They are seen in vast numbers throughout the Pacific Northwest. With a total population of $175,000-300,000$, the actual number found off Oregon is unknown, but California sea lions on the lower Columbia River have been estimated at 1,200 (ODFW, 2003), and the numbers off Oregon and Washington have been steadily increasing.

\section{Northern Elephant Seals (Mirounga angustirostris)}

The northern elephant seal is the largest phocid pinniped in the northern hemisphere, with males reaching over two tons and females just over 1000 pounds at maximum weight (Le Boeuf et al., 2000). Males are distinguishable from their immense size and inflatable proboscis. Just after molting, adults and juveniles are dark and become brown to tan over the next several months. Males can look extremely worn and mottled with a pink or light brown pelage, but are predominantly dark in color. Females are typically 
dark brown with lighter colors ventrally. Pups are black at birth and molt to a silver color within a few months (Reeves et al., 2002).

There are several northern elephant seals rookeries in California and Baja, but there are also two near the Oregon border at Cape Arago and Cape St. George. The only rookery north of Oregon is on Vancouver Island. During the winter months, northern elephant seals can be found at these sites, but the majority of their time is spent foraging. Northern elephant seals have one of the largest feeding ranges of any pinniped. They have been shown to forage from California to the Aleutian Islands, AK (Le Boeuf et al., 2000). Their prey are typically deep water squid, skates, rays, and occasionally rockfish (Reeves et al., 2002; Le Boeuf et al., 2000). Elephant seals are deep diving mammals. They have been recorded to dive to depths of $5000 \mathrm{ft}$. (DeLong and Stewart, 2006), putting them in closer range of prey close to hydrothermal vents.

Adult male northern elephant seals are not commonly found in Northern Oregon/So. Washington; juveniles and weaner males and females primarily make up the documented strandings (Duffield, pers. comm.). The overall population of northern elephant seals is estimated at 150,000 (Reeves et al., 2002). 
Harbor Seal (Phoca vitulina richardsi)

Harbor seals are phocid pinnipeds that can be a wide variety of colorations from solid dark grey to mottled brown (Reeves et al., 2002). Harbor seals are medium sized phocids in which males can reach 350 pounds with females weighing a maximum of 280 pounds.

Harbor seals have a large worldwide distribution with multiple subspecies (Brookens et al., 2008). The North Pacific harbor seal (Phoca vitulina richardsi) ranges from Baja, California, to the Aleutian Islands of Alaska (Reeves et al., 2002), and are thought to be locally distributed in discrete subpopulations. Pacific harbor seal populations are found along the entire West Coast with several thousand seals living at the Channel Islands off of southern California and a population estimated at 16,000 between Oregon and Washington (Brookens et al., 2008; NOAA, 2003). Harbor seals feed on small schooling fish, octopus, and squid. Pups will forage for slow moving shrimp and switch to faster moving capelin as their swimming skills improve (Reeves et al., 2002).

Harbor seal populations are estimated at 300,000 to 500,000 worldwide (Sea World, 2005). In the Gulf of Alaska, harbor seal populations declined in the 1970's and 1980's due to commercial trawl fisheries. In the Pacific Northwest, harbor seals are also exposed to pressure from commercial and recreational fisheries. 
Harbor Porpoise (Phocoena phocoena)

The only cetacean (whales and dolphins) in this study, the harbor porpoise is a small, fuselage-shaped animal. Males are typically smaller than females and can reach 130 pounds (Harms et al., 1997). Females are slightly larger and can reach 160 pounds as an adult. Their coloration is usually gray dorsally, with lighter sides and belly. They have a triangular dorsal fin that is dark grey, as are the color of its flippers (Reeves et al., 2002).

Harbor porpoises are found only in the northern hemisphere and, as their name implies, are coastal, found in fjords, bays, estuaries, and harbors (Reeves et al., 2002). The Pacific population has a large range from Monterey Bay all the way north to the Chukchi Sea, including the Aleutian Islands of Alaska (Reeves et al., 2002). Six stocks of harbor porpoises have been identified on the West Coast of the United States (Chivers et al., 2002), with a stock specific to the Oregon/Washington coast (Laake et al., 1998). Harbor porpoises feed on schooling fish, herring, squid, and octopus (Reeves et al., 2002).

Little is known about harbor porpoise ecology. Groups of 10 to 100 animals have been seen feeding together (Read, 1981). In the Oregon Stranding Network area, harbor porpoises are known to seasonally move along the Oregon coast, probably associated with feeding. The Oregon/Washington harbor porpoise population is estimated at 11,599 animals (Laake et al., 1998). Although populations in the northwest Pacific 
are considered stable, a threat exists from commercial fisheries using gillnets (Reeves et al., 2002).

\subsection{Current Study}

There is a paucity of literature on mercury in marine mammals from Oregon. The only previous published study of mercury in marine mammal muscle tissue was done by Buhler et al. (1974) on California sea lions (0.84$1.64 \mathrm{ppm} w w)$. Since mercury pollution is primarily related to the combustion of fossil fuels, human population size should have an indirect effect by increasing the availability of pollutants to the environment. The human population in Oregon has nearly doubled since 1970, and one would predict this to significantly increase the amount of mercury found in rivers and oceans. Furthermore, trade winds from China deposit mercury from coal burning power plants into the waterways and soils (Tang et al., 2007; Kleypas and Yates, 2009), and this source of mercury increases every week with the continuous addition of new coal burning power plants. This study is designed to investigate whether mercury concentrations in muscle tissue have increased since the previous study in Oregon due to prolonged and higher levels of exposure. I am also testing whether mercury in muscle will increase with the age of the animal, reflecting accumulation over time, and whether there are differences in bioaccumulation between males and females. 
The results of this study have been accepted for publication in Marine Mammal Science. The accepted manuscript is presented in Chapter 2. 
Chapter 2

\section{Marine Mammal Science Journal Publication ${ }^{1}$}

\subsection{Introduction}

Mercury contamination of marine mammals on the west coast of the United States can come from multiple sources including mine tailings, hydrothermal vents, municipal wastes and trade winds which carry volatized mercury across the Pacific Ocean from Asia (Klangsin and Harding 1998, Lamborg et al. 2006, Tang et al. 2007, Manning 2009). Several areas in California and throughout the northern Pacific have well documented mercury contamination in coastal waterways (Beckmen et al. 2002, Brookens et al. 2008). Major metropolitan areas such as Portland, OR and Vancouver, WA border the Columbia River that empties into the Pacific Ocean. The Portland Harbor Superfund site located along the Willamette Fork of the Columbia River has been shown to contain fish with mercury concentrations of up to $0.520 \mathrm{mg} / \mathrm{kg}$ ww (Sethajintanin et al. 2004). Further upriver from the Willamette Fork of the Columbia is the NPL Superfund site, the Black Butte mine (www.epa.gov), which leaches mercury into the Coast Fork Willamette River. Mean fish fillet mercury concentrations from the Coast Fork (0.66 $\mathrm{mg} / \mathrm{kg} \mathrm{ww}$ ) are higher than concentrations at the EPA designated site downstream (Hope and Rubin 2005). A national monitoring study (1969-

\footnotetext{
${ }^{1}$ Wintle, Nathan J.P., Duffield, Deborah A., Barros, Nélio B., Jones, Ronald D., Rice, James M. Total Mercury in Stranded Marine Mammals from the Oregon and Southern Washington Coasts. Marine Mammal Science Accepted for publication November 2010.
} 
1991) of whole freshwater fish revealed that the highest mercury concentrations $(0.33-1.7 \mathrm{mg} / \mathrm{kg} \mathrm{ww})$, were found in northern squawfish (Ptychocheilus oregonensis) from the Columbia River basin (Henderson and Shanks 1973, Lowe et al. 1985). Few studies have investigated mercury pollution of Oregon coastal waters, largely due to the fact that Oregon has no large mercury point source situated near the coast (Park and Curtis 1997). Steller sea lions (Eumetopias jubatus), California sea lions (Zalophus californianus), and harbor seals (Phoca vitulina) in particular frequent these polluted waterways as well as the coastal areas, and are at risk of accumulating harmful concentrations of mercury. This has been proposed as a factor in the recent decline of Steller sea lions from the Prince William Sound and Southeast Alaska where mean levels of mercury in their hair was found to be $2.74 \mathrm{mg} / \mathrm{kg} \mathrm{ww}$ (Beckmen et al. 2002). Marine mammal species are extremely susceptible to mercury contamination from both natural and anthropogenic inputs (Eisler 2006), especially as marine mammals are located near or at the top of the food chain, making them effective bioindicators of mercury contamination (Chasar et al. 2009). The last study of mercury contamination in the muscle tissue of marine mammals from the Oregon coast is nearly three decades old (Buhler et al. 1975), highlighting the need for updated research on heavy metal contamination in these species.

Analyzing muscle tissue for mercury is toxicologically significant because unlike liver and kidney, muscle does not have the ability to form 
soluble complexes with cysteine or glutathione or produce metallothioneins, which can cleave the carbon-mercury bond and reduce monomethylmercury $\left(\mathrm{CH}_{3} \mathrm{Hg}^{+}\right)$into inorganic $\mathrm{Hg}$ (Goyer 1986). Furthermore, total mercury burden has been shown to be highest in muscle tissue, over both the liver and kidney, and is recommended for biomonitoring (Brookens 2008). Though mercury concentrations are pronounced in the liver (Anas 1974), most of this mercury is biologically unavailable due to selenium complexation (Smith and Armstrong 1978). Using total mercury (THg) in muscle tissue has the added benefit that it is almost entirely in the form of $\mathrm{CH}_{3} \mathrm{Hg}^{+}$(Gaskin et al. 1972). Monomethylmercury, in comparison to all other Hg species, readily crosses biological barriers such as the GI tract and deposits in vascular tissues (Elhassani 1983), establishing muscle as a toxicologically significant tissue.

Given the uncertainty of mercury exposure and accumulation in marine mammal species along the coasts of Oregon and southern Washington, we have determined $\mathrm{THg}$ in five species representing different foraging and habitat ranges using muscle samples available from the Oregon and southern Washington stranding networks. This study is the first to examine multiple species from the Oregon coast. 


\section{Materials and methods}

\subsection{Sample collection}

Muscle samples from 105 marine mammals: 31 California sea lions (29 male, 1 female, 1 unknown), 27 Steller sea lions (10 male, 17 female), 21 harbor porpoises (Phocoena phocoena) (12 male, 7 female, 2 unknown), 18 harbor seals ( 8 male, 9 female, 1 unknown), and 8 elephant seals (Mirounga angustirostris) (6 male, 2 female), were obtained from necropsies of stranded animals along the Oregon and southern Washington coasts from 2002-2009 (Fig. 1). Muscle tissue was removed from the dorso-lateral or ventral subscapular region, immediately bagged and placed on ice. Samples were stored at $-20^{\circ} \mathrm{C}$ until analyzed. Morphological data including sex, length, decomposition code, and gross findings were recorded during the necropsy. The majority of the stranded animals were from northern Oregon between Cannon Beach and Astoria, $n=75$. The remaining strandings were from Long Beach, WA or along central Oregon to Bandon, $n=21$ and 9, respectively. Two California sea lion samples were from animals that died near the Columbia Fork on the Willamette River (see Appendix A). 


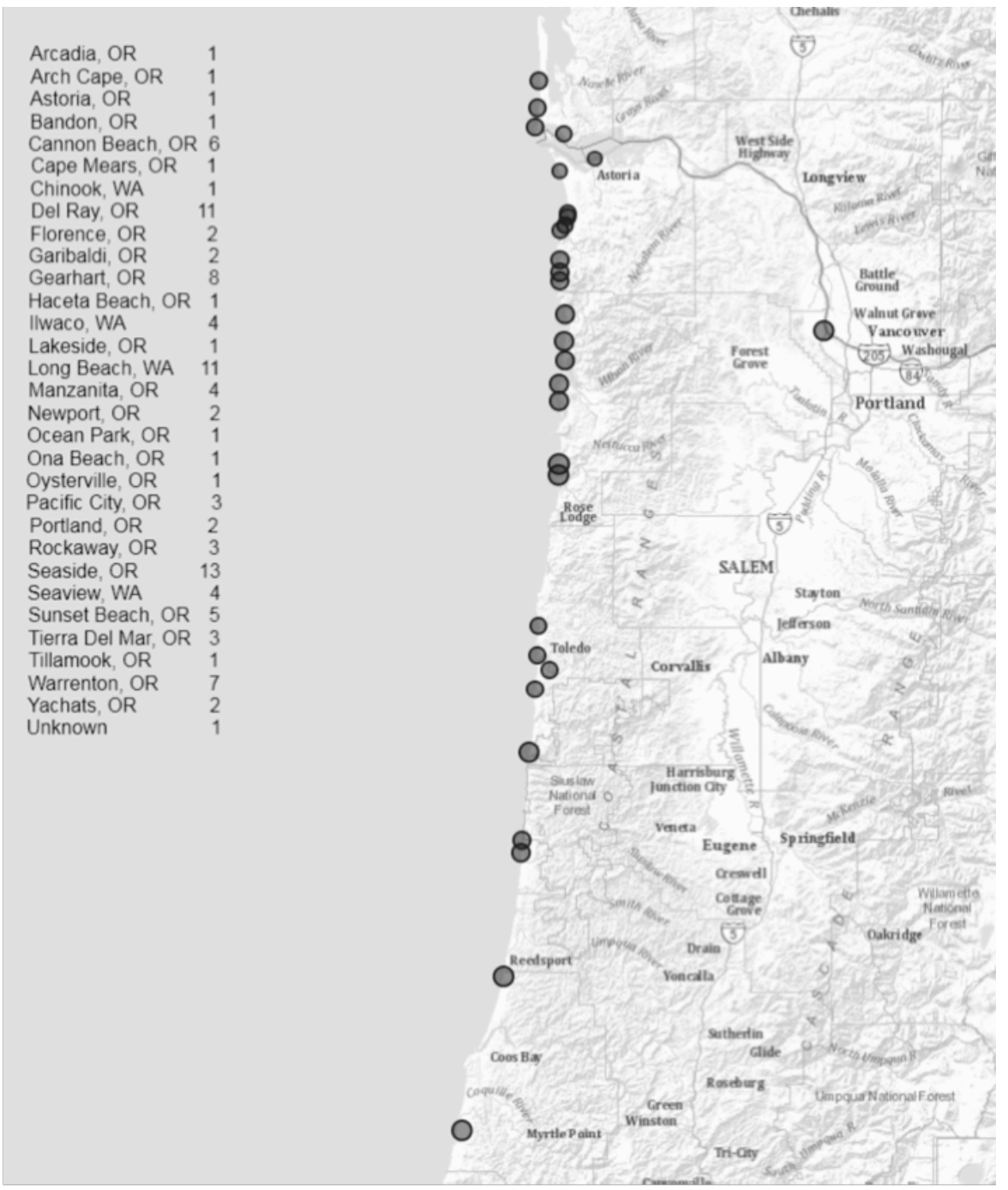

Fig. 2.1- Locations of strandings sampled from Oregon and Washington, 2002-2009. Value next to city name indicates number sampled.

\subsection{Chemical analysis}

Muscle tissue was digested in $10 \mathrm{~mL}$ glass ampules with $2 \mathrm{~mL} \mathrm{HNO}_{3}$ and $1 \mathrm{~mL}$ of $\mathrm{H}_{2} \mathrm{O}$ following the closed-ampule digestion procedure described by Jones et al. (1997), and mercury levels were determined by Cold Vapor Atomic Fluorescence Spectrometry. All Hg analyses were performed on a 
10.025 Millennium Merlin Hg analyzer from PS Analytical (Deerfield Beach, FL). In this analysis the digested tissue sample reacts with stannous chloride to convert $\mathrm{Hg}^{2+}$ from the samples into $\mathrm{Hg}^{\circ}$. The converted mercury is taken out of solution in a gas liquid separator by argon and detected by a fluorometer fixed at $254 \mathrm{~nm}$.

\subsection{Quality control}

Quality control followed the method established by Jones et al. (1997). A stock mercury reference standard $(100 \mathrm{~mL} \mathrm{Hg}$, Fisher Scientific) was used to prepare a calibration curve for each sample set. The method blank ( $1 \%$ $\mathrm{HCl}$ ), and a $5.0 \mathrm{mg} / \mathrm{kg}$ spike were injected into an ampule prior to nitric acid digestion for the last set. The recovery rates for both the blank and the spike were within the acceptable EPA range at $0.0 \%$ and $2.6 \%$ difference, respectively. Roughly $5 \%$ of the samples were run as duplicates, with a relative percentage difference of $33 \%$. During operation, each sample was run twice and averaged.

\subsection{Data analysis}

The degree of decomposition of tissues from individual stranded marine mammals varied greatly, leading to variability in the amount of water in each sample. To correct for this variance in percentage water, a $0.5 \mathrm{~g}$ plug from each tissue sample was desiccated in a vacuum centrifuge (SC210A 
Speedvac plus) for $12 \mathrm{hrs}$ to determine dry weight. The range of tissue water weight among samples was 29.4-73.9\%. Given the considerable range of percentage water seen among the stranded samples, the detected THg wet weight values for each animal were normalized by re-calculating individual levels based on a standard muscle water content of 75\% (Skelton 1925). Normalized values were calculated by comparing wet and dry weights for each sample to determine $\%$ water content and using this $\%$ in the following formula: $[\mathrm{mg} / \mathrm{kg}$ of $\mathrm{THg}$ before desiccation $](\%$ water loss $)=[$ normalized $\mathrm{mg} / \mathrm{kg}](0.75)$. Normalized values were used in the statistical analyses.

\subsection{Statistics}

A Shapiro-Wilk test for normality was run on the normalized values. Since these values were not normally distributed, all values were log transformed for further statistical analysis. Log transformed data for all species with the exception of Steller sea lions, also failed the Shapiro-Wilk test for normality. Therefore a parametric statistic (t-test) was used to test $\mathrm{THg}$ between sexes for Steller sea lions, but all other species were analyzed using the non-parametric Wilcoxan test. Linear regression was performed to look for an association of $\mathrm{THg}$ with length (an estimate of age). To test for significance among age classes within each species, the Kruskal-Wallis nonparametric test was run on each species except Steller sea lions, in which a one-way ANOVA was used to test for significance. All statistical analyses 
were run using SPSS statistical software (version 18.0.), with a significance level of (0.05).

\subsection{Results}

Of the five species examined, the highest mean concentrations of normalized THg were found in Steller sea lions and northern elephant seals, followed by harbor seals, harbor porpoises and California sea lions (Table 1; Appendix B). The distribution of individual values per species were skewed; therefore, species THg concentrations are given both as means and medians. Individual levels of normalized THg ranged from $0.00-1.50 \mathrm{mg} / \mathrm{kg}$.

There were no significant differences in normalized THg between sexes in any of the species examined (although only one female California sea lion was tested). While there was a trend of increasing mean normalized wet weight with age cohort (Table 2), the differences between age cohorts were not statistically significant. We found no significant correlation between length and normalized THg concentrations for all species.

\subsection{Discussion}

We report here findings on total mercury concentration from muscle tissue in Pacific Northwest marine mammals. For the five species that we tested, the reported mean and median normalized wet weight values and ranges indicate varying degrees of $\mathrm{THg}$ accumulation in marine mammals off 
the Oregon and southern Washington coasts. Steller sea lions and elephant seals had the highest mean values, but overall, normalized $\mathrm{THg}$ values ranged from $0.00-1.50 \mathrm{mg} / \mathrm{kg}(\mathrm{ppm})$ with the highest concentration noted in an adult elephant seal (Table 2.1).

Although numerous studies exist on mercury in marine mammals, few have reported $\mathrm{THg}$ concentrations from muscle tissue, which does not readily demethylate monomethylmercury and is the best overall indicator of accumulation (Buhler et al. 1975, Mieiro et al. 2009). Table 3 summarizes reported muscle THg concentrations for four of the five species we studied. Steller sea lions and northern elephant seals exhibited a normalized mean concentration of $0.34 \mathrm{mg} / \mathrm{kg} \mathrm{THg}$ in our study. Previous studies from the Aleutian Islands, AK reported a single Steller sea lion with a muscle concentration of $1.65 \mathrm{mg} / \mathrm{kg} \mathrm{ww}$ (Beckmen et al. 2002) and females, pups and males with muscle concentrations of $0.15,0.22$ and 0.26 mean $\mathrm{mg} / \mathrm{kg} \mathrm{ww}$, respectively (Holmes et al. 2008). No previous mercury levels were available for Steller sea lions from Oregon, Washington or California waters. This is the first report for northern elephant seal $\mathrm{THg}$ concentrations in muscle. The previously reported muscle concentrations for harbor seals from central California and Eastern Canada were 0.75 and $0.71 \mathrm{mg} / \mathrm{kg} \mathrm{THg}$ ww mean and mg/kg THg ww, respectively (Sergeant and Armstrong 1973, Brookens et al. 2008). For harbor seals our normalized mean concentration $(0.21 \mathrm{mg} / \mathrm{kg}$ 


\begin{tabular}{|c|c|c|c|c|c|c|}
\hline 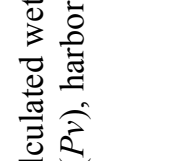 & 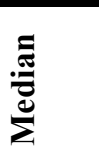 & $\tilde{\overbrace{}}$ & $\frac{\infty}{\oplus}$ & $\frac{n}{8}$ & $\frac{ \pm}{\theta}$ & $\frac{m}{9}$ \\
\hline 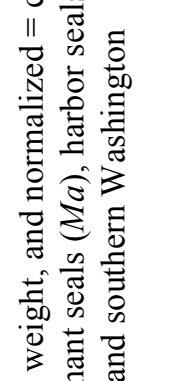 & 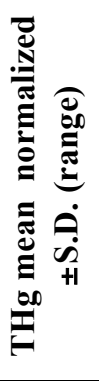 & 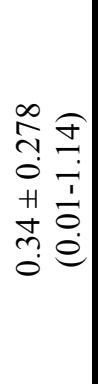 & 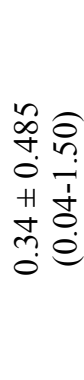 & 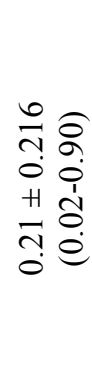 & 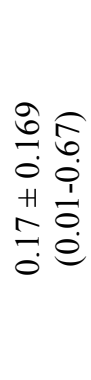 & 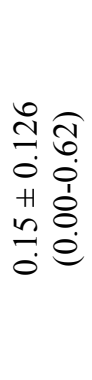 \\
\hline 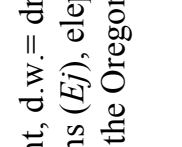 & : & $\frac{m}{i}$ & $\stackrel{ \pm}{ \pm}$ & $\stackrel{\infty}{\rightleftarrows}$ & $\stackrel{\circ}{\circ}$ & $\stackrel{\infty}{\infty}$ \\
\hline 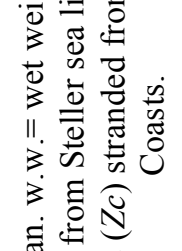 & 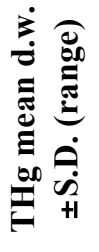 & 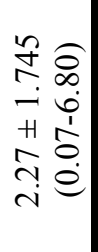 & 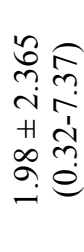 & 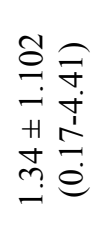 & 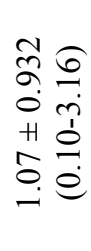 & 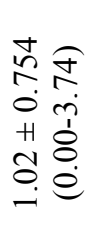 \\
\hline 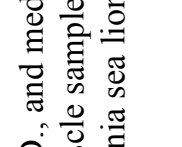 & 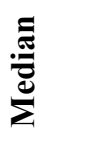 & $\stackrel{9}{=}$ & है? & $\stackrel{R}{\stackrel{R}{\theta}}$ & $\stackrel{n}{\circ}$ & $\stackrel{0}{\stackrel{0}{0}}$ \\
\hline 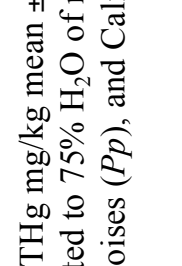 & 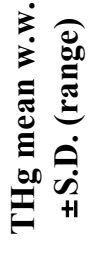 & 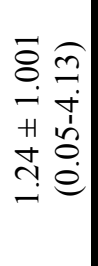 & 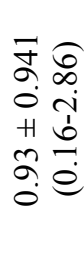 & 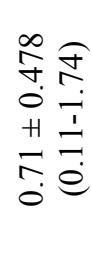 & 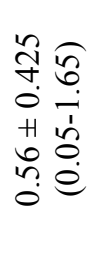 & 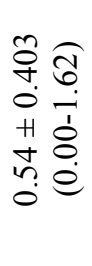 \\
\hline 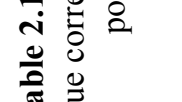 & $=$ & $\hat{\sim}$ & $\infty$ & $\stackrel{\infty}{\infty}$ & $\bar{\sim}$ & $\bar{m}$ \\
\hline 苟 & $\dot{\dot{n}}$ & 四 & $\sum^{\pi}$ & $\overrightarrow{2}$ & 2 & $\stackrel{\Xi}{N}$ \\
\hline
\end{tabular}


Table 2.2- Species cohorts normalized $\mathrm{THg} \mathrm{mg} / \mathrm{kg}$ mean \pm S.D. and range. $\mathrm{n}=$ cohort size

\begin{tabular}{|c|c|c|c|}
\hline Sp. & Cohort & n & $\begin{array}{l}\text { Normalized Mean } \pm \\
\text { S.D. (Range) }\end{array}$ \\
\hline $\mathrm{Zc}$ & $\begin{array}{l}\text { Pup............... } \\
\text { Juvenile.......... } \\
\text { Sub-Adult....... } \\
\text { Adult............. }\end{array}$ & $\begin{array}{c}- \\
- \\
5 \\
26\end{array}$ & $\begin{array}{c}\mathrm{na} \\
\mathrm{na} \\
.124 \pm .136(.04-.29) \\
.133 \pm .233(.00-1.19)\end{array}$ \\
\hline $\mathrm{Ma}$ & $\begin{array}{l}\text { Pup............... } \\
\text { Juvenile........... } \\
\text { Sub-Adult....... } \\
\text { Adult............ }\end{array}$ & $\begin{array}{l}2 \\
5 \\
- \\
1\end{array}$ & $\begin{array}{c}.095 \pm .063(.05-.15) \\
.214 \pm .159(.04-.43) \\
\text { na } \\
(1.50)\end{array}$ \\
\hline $\mathrm{Pv}$ & $\begin{array}{l}\text { Pup............... } \\
\text { Juvenile.......... } \\
\text { Sub-Adult....... } \\
\text { Adult............ }\end{array}$ & $\begin{array}{c}2 \\
2 \\
3 \\
11\end{array}$ & $\begin{array}{l}.030 \pm .014(.02-.04) \\
.165 \pm .021(.15-.18) \\
.116 \pm .083(.05-.21) \\
.283 \pm .250(.07-.90)\end{array}$ \\
\hline $\mathrm{Pp}$ & $\begin{array}{l}\text { Calf............... } \\
\text { Juvenile.......... } \\
\text { Sub-Adult....... } \\
\text { Adult............ }\end{array}$ & $\begin{array}{l}- \\
5 \\
7 \\
9\end{array}$ & $\begin{array}{c}\mathrm{na} \\
.088 \pm .067(.02-.17) \\
.161 \pm .156(.02-.50) \\
.225 \pm .207(.01-.67)\end{array}$ \\
\hline $\mathrm{Ej}$ & $\begin{array}{l}\text { Pup................ } \\
\text { Juvenile.......... } \\
\text { Sub-Adult....... } \\
\text { Adult............. }\end{array}$ & $\begin{array}{c}- \\
3 \\
2 \\
22\end{array}$ & $\begin{array}{c}\mathrm{na} \\
.016 \pm .005(.01-.02) \\
.190 \pm .183(.06-.32) \\
.400 \pm .270(.05-1.14)\end{array}$ \\
\hline
\end{tabular}

normalized ww) was considerably lower than either of these reported mean concentrations. No harbor porpoise mercury levels have previously been reported for the Pacific coast of the United States; however, mean muscle concentrations from the northern Altantic and adjacent waters, and the Black Sea of eastern Europe were found to range from 0.3 to $2.1 \mathrm{mg} / \mathrm{kg} \mathrm{THg}$ fw or ww (see Table 2.3). Our normalized harbor porpoise concentrations from the Pacific Northwest were also considerably lower than all previous studies $(0.17$ $\mathrm{mg} / \mathrm{kg}$ normalized ww). Similarly, the normalized muscle $\mathrm{THg}$ values for California sea lions evaluated in Oregon and southern Washington in this current study were lower than previously reported values for central Oregon 
(0.15 mg/kg normalized ww vs. 1.64 mean mg/kg THg ww; Buhler et al.

1975).

Table 2.3- Previous studies of mercury in muscle tissue by species and region.

\begin{tabular}{|l|c|c|}
\hline Region & Mean (mg/kg) & References \\
\hline Harbor Porpoise- & $0.9^{1}$ & Gaskin et al. (1979) \\
Bay of Fundy, Canada & $0.7^{1}$ & Westgate and Johnson (1995) \\
Northwest Atlantic & $1.4^{1,3}$ & Joiris et al. (1991) \\
North Sea \& Kattegat & $1.9^{1}$ & Andersen and Rebsdorff (1976) \\
Denmark & $2.1^{1,3}$ & Siebert et al. (1999) \\
German North Sea & $1.3^{1,3}$ & Siebert et al. (1999) \\
German Baltic Sea & $0.7^{1}$ & Szefer et al. (1995) \\
Polish Baltic Sea & $0.3^{1,3}$ & Joiris et al. (2001) \\
Black Sea & $1.65^{4,5}$ & Beckmen et al. (2002) \\
\hline Harbor Seal- & $0.15-0.26^{2,3}$ & Holmes et al. (2008) \\
Central California & $0.75^{1,3}$ & Brookens et al. (2008) \\
Eastern Canada & $0.71^{2,4,5}$ & Sergeant and Armstrong (1973) \\
\hline California Sea Lion- & $0.84-1.64^{2,3}$ & Buhler et al. (1975) \\
Central Oregon & & \\
\hline Steller Sea Lion- & & \\
Aleutian Islands, Alaska & & \\
\hline Northeastern Pacific & & \\
\hline
\end{tabular}

1-Reported values as fresh weight 3-Collected samples from strandings

5-Sample size of one animal
2-Reported values as wet weight 4-Unknown collection method 
current study were lower than previously reported values for central Oregon (0.15 mg/kg normalized ww vs. 1.64 mean mg/kg THg ww; Buhler et al. 1975).

A complication arose in the comparison of concentrations among studies related to the condition of muscle at the time of sampling. The muscle water content of the stranded animals in our study varied from $29 \%$ to $74 \%$ depending on the condition of the animal at the time of stranding. This difference in water content could give a false sense of $\mathrm{THg}$ accumulation and normalizing the wet weight allowed for a clearer indication of the amount of mercury the animal accumulated before stranding, facilitating comparisons between fresh tissue samples from a healthy animal and decomposed tissues from a stranded animal. Compensating for this by normalizing our wet weights to a standard vertebrate $75 \%$ muscle water content lowered the mean, median and range concentrations for all species when compared to the unnormalized wet/dry weight values (see Table 2.1). In looking at reported concentrations for these species, it was not always clear whether the samples were from freshly dead and non-dehydrated animals. It was therefore hard to evaluate whether the higher concentrations previously reported in harbor seals, harbor porpoises and California sea lions were affected by water loss or reflective of regional differences. On the other hand, wet weight (nonnormalized) would be of more importance for predators feeding on these carcasses on the beach. We have observed seagulls, crows and eagles feeding 
on carcasses in the Northern Oregon/Southern Washington stranding region and it is the higher mean wet weight concentrations (Table 2.1) that closer reflect their risk of bioaccumulation.

Previous studies by Gaskin et al. (1972), Harms et al. (1978), Smith and Armstrong (1978), and Eisler (1984), reported that total mercury values increased with length (i.e., age). The concentrations they found were reported either as fresh weight or wet weight. After normalizing our data, we found no significant correlation between length and $\mathrm{THg}$ concentration for all species. When evaluated as age cohorts (Table 2.2), although there was a trend towards higher mean concentrations with age cohort, there was no statistical correlation between age and $\mathrm{THg}$ concentration.

Steller sea lions and northern elephant seals exhibited the highest concentrations of mercury in our study. It is not clear at this point whether exposure to and accumulation of mercury in these species is due to geographic range or prey choice. Both of these species move long distances in search of food along the west coast of the United States but prey upon different species with the northern elephant seal foraging further from shore (Brillinger and Stewart 1998, Pitcher et al. 2007). Harbor porpoises, which feed on a wide variety of pelagic and demersal prey, are also highly mobile with large home ranges (Reeves et al., 2002 et al. 2002), but had notably lower Hg levels. Harbor seals, thought to have more localized foraging ranges, closely matched levels found in the harbor porpoises, while California sea lions, which are 
highly mobile (Zuerner et al. 2009), also showed low levels of mercury accumulation.

\subsection{Conclusions}

Despite the recent increase in awareness of the hazards of mercury contamination, very little has been done to curtail its input into the ecosystem in Oregon and Washington (Seigneur et al. 2004, Harper and Harris 2008). For example, one such input comes from mine tailings at the head waters of the Willamette River, abandoned during the 1960's (Manning 2009), which are still leaching mercury into the environment (Chen et al. 2008). Furthermore, although few data exist on the prevalence of non-point source mercury pollution, such as that from the burning of fossil fuels, it is estimated that coal-burning in China is responsible for $21 \%$ of the total mercury deposition in the United States (Tang et al. 2007). Another possible source of mercury comes from natural sources such as hydrothermal vents near the Gorda Ridge off the coast of Oregon (Lamborg et al. 2006) and volcanic eruptions such as the Mt. St. Helens eruption of 1980 that spewed 97.7 metric tons of mercury into the atmosphere and surrounding area (Nriagu and Becker 2003). Concentrations of THg in muscle from the coastal Oregon and southern Washington marine mammal species reported here indicate limited accumulation. However, the significance of these findings depends on whether one is concerned about levels reflecting relative accumulation within 
these species $(0.00-1.50 \mathrm{mg} / \mathrm{kg}$ normalized ww) or upon the impact for scavengers feeding on the stranded carcasses $(0.00-4.13 \mathrm{mg} / \mathrm{kg} \mathrm{ww})$. We emphasize that muscle water content in dead marine mammals that have been on the beach for varying periods of time can inflate (often considerably) the apparent muscle wet weight values. It is apparent that mercury accumulation is not localized to highly populated areas, but is dispersed along the northwest coast and presumably transported by prevailing winds and from waterways such as the Columbia River (Tang et al. 2007, Brigham et al. 2009). Given this preliminary look at THg in marine mammals in the Pacific Northwest, we emphasize the need for closer monitoring of mercury loads in these species in order to more accurately track mercury trends over time. As more interest develops over reintroduction of key scavengers such as condors into the Northwest region (California Condor Recovery Program), the levels of mercury found in marine mammal carcasses along the coast becomes a very real concern. 


\section{Chapter 3}

\section{Discussion}

\subsection{Marine Mammal Distribution}

Environmental mercury concentrations should be highest where there is a large input from human beings (Eisler, 2006, Tang et al., 2007, U.S. EPA, 2001), implying that the more time the animal spends near highly populated regions, the more mercury it should have. But in Oregon, there are also significant natural sources of mercury from hydrothermal vents. The Northern Oregon Marine Mammal Stranding Network responds to strandings of both year-round species such as Steller sea lions and harbor seals, and also to seasonal species such as California sea lions, elephant seals and harbor porpoises. Since, the primary route of THg accumulation in marine mammals would be from feeding on mercury contaminated prey (Eisler, 2006), prey near hydrothermal vents could be especially vulnerable to mercury accumulation up the food chain. Therefore, animals living around these tectonic areas will be exposed mercury more often than seasonal migrants into the region. Differences in diet could also be a major determinant of accumulated mercury levels. Hydrothermal vents off of the Oregon coast emit a large amount of mercury which bioaccumulates up the food chain and large fish and cephalopods contain higher levels of mercury than small schooling fish and crustaceans (Harms et al., 1978). 
Total mercury concentrations reflected each of the five species' diets and distribution (Reeves et al., 2002). The main corollary to THg mean concentration seemed to be individual species' distribution. For example, Steller sea lions exhibited the highest mean total mercury concentration. They breed off the southern Oregon coast and are found along the Oregon/Washington coast year round. California sea lions exhibited the lowest mean THg concentration, and only seasonally forage in Oregon. Northern elephant seals also exhibited higher levels of THg concentrations, and have rookeries that are established on the southern Oregon coast. In addition, these are the deepest diving, northern hemisphere pinniped and being able to feed on deeper prey may also be an important factor to mercury exposure. Harbor porpoises (with lower mean THg levels like California sea lions) are found more frequently stranded from late spring to early fall and may be more seasonal in Oregon/Washington waters following schooling fish, such as anchovies, sardines and herring.

Tectonic activity is a primary demographic cause for elevated total mercury concentrations (Tunnicliffe et al., 1996, Lamborg et al., 2006). Particularly in southern Oregon and along the Oregon coast, the plate boundaries between the Pacific Plate, the Jaun de Fuca Plate, and the North American Plate are high in tectonic activity and give rise to hydrothermal vents (Lamborg et al. 2006). This activity is part of the "Ring of Fire", which circles the entire Pacific Ocean (Tupper et al. 2004). At these plate 
boundaries large amounts of methylmercury are released into the surrounding sediments and organisms at concentrations up to 5.8-17.3 ppm (Lamborg et al., 2006). Methylmercury is taken up by benthic fauna and squid and then bioaccumulated up through the marine food web (Reeves et al., 2002; Chen et al., 2008). Although, most of the mercury is deposited onto the seafloor, these vents can disperse their plumes up to 2000 meters into the water column (Baker et al., 1995). These vents are often too deep for most marine mammals to reach, even at their greatest recorded diving depths (Reeves et al., 2002). However, the hydrothermal vents on the Juan de Fuca Ridge are anywhere from 1500 to 2600 meters deep and with plumes that can extend 2000 meters to the surface (Lucas 1972); this brings the direct source of mercury into the range of prey on which coastal marine mammals are foraging.

A second variable that may be important in explaining the observed mercury levels relates to trade winds and Pacific Gyre movements which bring mercury pollutants to the west coast of the United States from China. This source of mercury first affects the Aleutian Islands of Alaska and then is moved several thousand miles south along the west coast of the United States to California (Kleypas and Yates, 2009). Because the distance that the wind and water must travel before reaching Alaska is considerably less than the distance to California (Kleypas and Yates 2009), a higher concentration of mercury is deposited in the waters of Alaska compared to Californian waters 
(Tang et al. 2007). The species with a more northern range (particularly

Steller sea lions and northern elephant seals) exhibit higher mean levels of mercury than the more locally distributed or southern species (harbor seal, harbor porpoise and California sea lion; Table 2.1).

\subsection{Interpreting THg Data}

Analyzing tissue as dry weight requires desiccating the tissue being analyzed in order to quantify the percentage water present in the collected wet weight sample. Although the wet weight sample provides an estimate of the $\mathrm{THg}(\mathrm{mg} / \mathrm{kg})$ present in a carcass on the beach, reporting $\mathrm{THg}$ concentrations as dry weight has the advantage of being comparable. When sampling was limited to beach-cast animals, I found that the water content of the muscle varied considerably from individual to individual (Table 3.1). This was due

Table 3.1-Percent water weight \pm S.D., range in parenthsis. The variation in $\% \mathrm{H}_{2} \mathrm{O}$ could be due to a large number of factors including sickness at stranding, time on beach or time in storage.

\begin{tabular}{|c|c|c|}
\hline Species & $\mathbf{n}$ & $\begin{array}{c}\% \mathbf{H}_{2} \mathbf{O} \text { mean } \pm \\
\text { S.D. (range) }\end{array}$ \\
\hline Steller sea lion & 27 & $\begin{array}{c}43.9 \pm 8.5 \\
(29.4-67.5)\end{array}$ \\
\hline N. Elephant seal & 8 & $\begin{array}{c}49.1 \pm 11.6 \\
(37.6-73.9)\end{array}$ \\
\hline Harbor seal & 18 & $\begin{array}{c}44.4 \pm 8.2 \\
(35.2-58.4)\end{array}$ \\
\hline Harbor porpoise & 21 & $\begin{array}{c}44.5 \pm 7.8 \\
(32.3-64.3)\end{array}$ \\
\hline CA sea lion & 31 & $\begin{array}{c}46.4 \pm 8.2 \\
(33.9-65.4)\end{array}$ \\
\hline
\end{tabular}


to a combination of factors, including loss of water in decomposing carcasses, illness and dehydration in the animal which had caused it to strand, or simply water loss on subsequent tissue storage. Mercury analyses reported as $\mathrm{THg}$ concentrations dry weight remove this bias and allow inter-individual and inter-species comparisons.

These dry weight values can be normalized to a muscle water percent (here chosen to be $75 \%$ water; Skelton, 1925) for comparison with literature values taken on fresh animals. In this study these normalized values were used to compare mercury values in the literature to mercury values in the studied species (see Chapter 2).

A caveat to this is that mercury levels being bioaccumulated from dead marine mammal carcasses by scavengers such as gulls, ravens, eagles and coyotes (as observed by NOSWSN) are based on the wet weight of the tissues ingested. Given the range of water loss in stranded marine mammal muscle (Table 3.1), the actual exposure level to $\mathrm{THg}(\mathrm{mg} / \mathrm{kg} \mathrm{ww})$ can be much higher than the normalized values I report for comparative purposes (Appendices $\mathrm{B}, \mathrm{C}, \mathrm{D})$.

\section{Steller Sea Lions vs. California Sea lions - wet weight THg levels}

In Oregon, Steller sea lions are often seen with California sea lions. Both species are also seen up the Columbia River taking salmon and sturgeon (Wright et al., 2007), and along the Oregon coast on jetties and rocky 
outcrops. These two species have overlapping ranges in Oregon and Washington and overlapping prey choices (Reeves et al., 2002), but were significantly different when analyzed for THg concentrations. Steller sea lions had the highest mean wet weight concentration of THg (1.24 ppm ww) and California sea lions had the lowest (0.54 ppm ww).

Steller sea lion home ranges extend from southern Oregon to the Aleutian Islands of Alaska. Resident Steller sea lions have established rookeries in southern Oregon with a steadily increasing population of over 2000 (Oregon Sea Grant, 2003). Steller sea lions feed on a wide variety of prey including sturgeon, steelhead, rockfish, walleye, herring, cod, squid and octopus. In southern Oregon particularly, these prey come from the areas exposed to mercury-contaminated hydrothermal vents (Tunnicliffe, 1986). The length of time per year that Steller sea lions spend feeding in mercury polluted waters is possibly far greater than California sea lions which feed in these same areas only six to seven months of the year and have the more southern distribution of the two species (Van Dover, 2010). The reason we are seeing differences in mercury concentration may simply be due to the time that these two species spend feeding in contaminated areas.

\section{Northern Elephant Seals - wet weight THg levels}

Northern elephant seals contained the second highest mean wet weight concentration of total mercury in this study $(0.94 \mathrm{ppm} w w)$. Elephant seals 
swim and feed in tectonically active waters off the Oregon coast (Le Boeuf et al., 2000). The breeding grounds for elephant seals are off the southern California coast on the Channel Islands and also in the San Francisco Bay area (Le Boeuf et al., 2000). Though they do not breed as far north as Steller sea lions, they have recently established rookeries in southern Oregon. In the nonbreeding season, they range as far north as the Aleutian Islands of Alaska, generally feeding on deeper prey such as squid, skates, rays and more coastally, rockfish. Swimming in areas as far north as the Alaskan Gulf would put elephant seals in waters that are tectonically active as well as polluted by trade winds and the Pacific Gyre similar to Steller sea lions (Kleypas and Yates, 2009). Northern elephant seals are one of the deepest diving of the pinniped species, staying over an hour at depths of up to $5000 \mathrm{ft}$. (Reeves et al., 2002). At this depth, they could indeed be feeding on the highly contaminated benthic fauna near hydrothermal vents.

\section{Harbor Seals and Harbor Porpoises - wet weight THg levels}

Total mean mercury wet weight concentrations for harbor seals were $0.71 \mathrm{ppm} w \mathrm{w}$, while harbor porpoises were slightly less at $0.56 \mathrm{ppm}$ ww. Both the harbor seal and harbor porpoise are smaller marine mammals that feed on migrating schooling fish, as well as squid (Brookens et al. 2008; Joiris et al. 2001). Harbor seals, with a slightly higher mean THg wet weight concentration, can be found in Oregon all year long while the harbor porpoise, 
which had a lower mean $\mathrm{THg}$ concentration, seems to seasonally move throughout Oregon waters (Lamborg et al. 2006). Harbor porpoises are also commonly found off Oregon during the calving season. The higher concentration of total mercury in harbor seals versus harbor porpoises may reflect both annual geographical distribution and differences in preferred prey distribution. Both species are less exposed to mercury pollution than Steller sea lions and northern elephant seals.

\subsection{Conclusion}

I had hypothesized that exposure of Pacific Northwest marine mammals to mercury would have increased since the previous study of Buhler et al. (1975). They reported mean THg concentrations of 0.84-1.64 ppm ww in California sea lions from the central Oregon coast. In my sampling of California sea lions from central to northern Oregon, I found a mean of 0.54 ppm ww. The level in California sea lions had not appreciably increased, and had in fact significantly decreased. There were no comparable levels available for the rest of the species studied in Oregon.

Also, previous studies on mercury (Gaskin et al., 1972; Holden, 1975; Harms et al., 1978; Smith and Armstrong, 1978; Eisler, 1984) showed that the age of the animal was in direct relation to the amount of mercury they had accumulated. I saw a similar result for Steller sea lion dry weight and wet weight ( $\mathrm{p}=.025$ and $\mathrm{p}=.042$, respectively), harbor seal dry weight $(\mathrm{p}=.050)$, 
and harbor porpoise dry weight and wet weight $(\mathrm{p}=.004$ and .045 ,

respectively; Table 3.2 and Chapter 2; Appendix E). Elephant seals and

California sea lions did not exhibit statistically significant changes within

mercury concentration with respect to age. Total mercury was not

significantly correlated with the health status of the stranded animal in any of

the species (Appendix F).

Table 3.2- All three methods for reporting mercury concentrations were analyzed for significance between $\mathrm{THg}$ and the age of the animal. Significance level of 0.05. A significant value is indicated by bold.

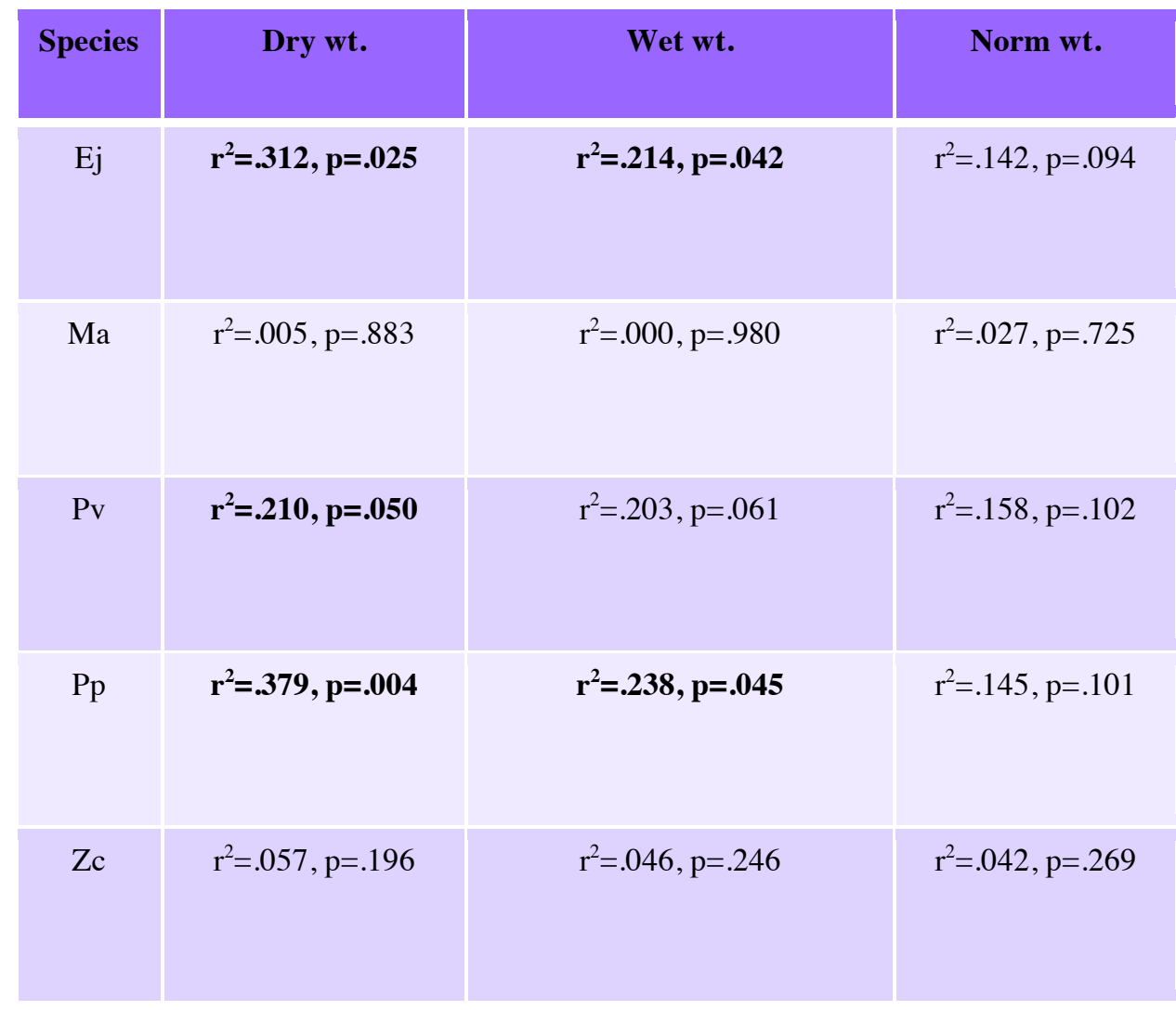

Mercury is found worldwide, from the deepest trenches in the ocean to the highest mountaintops. Although mercury is classified as a heavy metal, it 
can take the form of a gas, a liquid, or a solid. The amount of mercury that enters the environment as a direct consequence of human activity is significantly less than the amount coming from natural processes such as hydrothermal vents; however, anthropogenic sources of mercury are increasing. It was refreshing to find that, in general, and despite both natural and anthropogenic mercury being high in Oregon waters, the levels seen in marine mammals on our coast were still relatively low when compared with levels reported for some of these species in other waters (see Chapter 2). A detailed protocol for total mercury analysis is given in appendix G.

The continued monitoring for mercury in marine mammals is a worthwhile study. These species represent important sentinels of pollution in the marine environment. The availability of tissue for analysis from animals that strand makes the monitoring of mercury a feasible endeavor. Furthermore, the suggestion that mercury from hydrothermal vent activity off the Oregon coast may account for levels of mercury in species such as the Steller sea lion, emphasizes the importance of initiating studies on mercury levels in coastal fish stocks that are primary prey items for marine mammal species. 
LITERATURE CITED

Akagi, H. and Nishimura, H. (1991) 'Advances in Mercury Toxicology', Plenum Press, New York.

Anas, R. E. (1974) 'Heavy metals in northern fur seals, Callorhinus ursinus, and harbor seals, Phoca vitulina richardi', Fishery Bulletin 72, 133137.

Andersen, S. H. and Rebsdorff, A. (1976) 'Polychlorinated hydrocarbons and heavy metals in harbour porpoises (Phocoena phocoena) and whitebeak dolphins (Lagenorhynchus albirostris) from Danish waters', $4,1-7$.

Baker, E.T., German, C.R., Elderfield, H. (1995) 'Hydrothermal Plumes Over Spreading-Center Axes: Global Distributions and Geological Inferences', Seafloor Hydrothermal Systems: Physical, Chemical, Biological, and Geological Interactions, 91, 47-71.

Beckmen, K. B., Duffy, L. K., Zhang, X. M. and Pitcher, K. W. (2002) 'Mercury concentrations in the fur of Steller sea lions and northern fur seals from Alaska', Marine Pollution Bulletin, 44(10), 1130-1135.

Birge, W.J., Black, J.A., Westerman, A.G. and Hudson, J.E. (1979) 'The effect of mercury on reproduction of fish and amphibians', In J.O. Nriagu (Ed.), The Biogeochemistry of Mercury in the Environment, p. 629-655. Elsevier/North-Holland Biomedical Press, New York.

Bloom, N.S. (1989) 'Determination of picogram levels of methylmercury by aqueous phase ethylation, followed by cryogenic gas chromatography with cold vapor atomic fluorescence detection. Can J Fish Aquat Sci 46, 1131-1140.

Brigham, M. E., Wentz, D. A., Aiken, G. R. and Krabbenhoft, D. P. (2009) 'Mercury Cycling in Stream Ecosystems. 1. Water Column Chemistry and Transport', Environmental Science \& Technology, 43(8), 27202725 .

Brillinger, D. R. and Stewart, B. S. (1998) 'Elephant-seal movements: Modelling migration', Canadian Journal of Statistics-Revue Canadienne De Statistique, 26(3), 431-443. 
Brookens, T. J., O'Hara, T. M., Taylor, R. J., Bratton, G. R. and Harvey, J. T. (2008) 'Total mercury body burden in Pacific harbor seal, Phoca vitulina richardii, pups from central California', Marine Pollution Bulletin, 56(1), 27-41.

Buhler, D. R., Claeys, R. R. and Mate, B. R. (1975) Heavy Metal and Chlorinated Hydrocarbon Residues in California Sea lions, 32, J. Fish. Res. Board Can.

Calambokidis, J. and Barlow, J. (1991) 'Chlorinated hydrocarbon concentrations and their use for describing population discreteness in harbor porpoises from Washington, Oregon, and California. Reynolds, J.E., III, and D.K. Odell (eds.), Proceedings of the second marine mammal stranding workshop: 3-5 December 1987, Miami, Florida. NMFS, NOAA Tech. Rep. NMFS 98:101-110.

Calkins, D.G., Mallister, D.C., Pitcher, K.W. and Pendleton, G.W. (1997) 'Steller Sea Lion Status and Trend in Southeast Alaska: 1979-1997', Marine Mammal Science, vol. 15(2), 462-477.

Chasar, L. C., Scudder, B. C., Stewart, A. R., Bell, A. H. and Aiken, G. R. (2009) 'Mercury Cycling in Stream Ecosystems. 3. Trophic Dynamics and Methylmercury Bioaccumulation', Environmental Science \& Technology, 43(8), 2733-2739.

Chen, C., Amirbahman, A., Fisher, N., Harding, G., Lamborg, C., Nacci, D. and Taylor, D. (2008) 'Methylmercury in Marine Ecosystems: Spatial Patterns and Processes of Production, Bioaccumulation, and Biomagnification', Ecohealth, 5(4), 399-408.

Chivers, S.J., Dizon, A.E., Gearin, P.J. and Robertson, K.M. (2002) 'Smallscale population structure of eastern North Pacific Harbour porpoises (Phocoena phocoena) indicated by molecular genetic analyses. $J$. Cetacean Res. Manage. 4(2), 111-122.

Dempsey, T. (2010) 'Oregon, USA Observations on the Oregon coast'. www.photoseek.com/ORusa.html accessed 2011

Delong, R.L. and Stewart, B.S. (2006) 'Diving Patterns of Northern Elephant Seal Bulls', Marine Mammal Science, vol. 7(4), 369-384.

Duffy, L. K. (2009), Fairbanks: University of Alaska, unpublished. 
Eisler, R. (2006) Mercury: Hazards to Living Organisms, Boca Raton: Taylor \& Francis Group.

Elhassani, S. B. (1983) 'The many faces of methylmercury poisoning', Clinical Toxicology, 19(8), 875-906.

Fiscus, C.H. and Baines, G.A. (1966) 'Food and Feeding Behavior of Steller and California Sea Lions', Journal of Mammology, 195-203.

Gaskin, D. E., Ishida, K. and Frank, R. (1972) Mercury in harbour porpoises (Phocoena phocoena) from the Bay of Fundy region, 29, J. Fish. Res. Board Can.

Gaskin, D. E., Stonefield, K. I., Suda, P. and Frank, R. (1979) 'Changes in mercury levels in harbor porpoises from the Bay of Fundy, Canada, and adjacent waters during 1969-1977', 8, 733-762.

Gerstenberger, S.L., Martinson, A. and Kramer, J.L. (2009) 'An evaluation of mercury concentrations in three brands of canned tuna', Environmental Toxicology and Chemisty, vol. 29(2), 237-242.

Goyer, R. A. (1986) 'Toxic effects of metals', Casarett and Doull's Toxicology, 582-635.

Harms, U., Drescher, H. E. and Huschenbeth, E. (1978) 'Further data on heavy metals and organochlorines in marine mammals for German coastal waters', 26, 153-161.

Harper, B. L. and Harris, S. G. (2008) 'A possible approach for setting a mercury risk-based action level based on tribal fish ingestion rates', Environmental Research, 107(1), 60-68.

Henderson, C. and Shanks, W. E. (1973) Mercury concentrations in fish, Mercury in the Western Environment, Corvallis: Oregon State University.

Holmes, A. L., Wise, S. S., Goertz, C. E. C., Dunn, J. L., Gulland, F. M. D., Gelatt, T., Beckmen, K. B., Burek, K., Atkinson, S., Bozza, M., Taylor, R., Zheng, T. Z., Zhang, Y. W., Aboueissa, A. M. and Wise, J. P. (2008) 'Metal tissue levels in Steller sea lion (Eumetopias jubatus) pups', Marine Pollution Bulletin, 56(8), 1416-1421. 
Hope, B. K. and Rubin, J. R. (2005) 'Mercury levels and relationships in water, sediment, and fish tissue in the Willamette Basin, Oregon', Archives of Environmental Contamination and Toxicology, 48(3), 367380 .

Itano, K., S. Kawai, N. Miyazaki, R. Tatsukawa, and T. Fujiyama. (1984) Mercury and selenium levels in stripped dolphins caught off the Pacific coast of Japan, Agric. Biol. Chem., 48, 1117-1121.

Jackson, T.A. (1998) 'Mercury in aquatic ecosystems'. In W.J. Langston and M.J. Bebianno (Eds.), Metal metabolism in aquatic environments, $\mathrm{p}$. 76-157. Chapman \& Hall, London.

Joiris, C. R., Holsbeek, L., Bolba, D., Gascard, C., Stanev, T., Komakhidze, A., Baumgartner, W. and Birkun, A. (2001) 'Total and organic mercury in the Black Sea harbour porpoise Phocoena phocoena relicta', Marine Pollution Bulletin, 42(10), 905-911.

Joiris, C. R., Holsbeek, L., Bouquegneau, J. M. and Bossicart, M. (1991) 'MERCURY CONTAMINATION OF THE HARBOR PORPOISE PHOCOENA-PHOCOENA AND OTHER CETACEANS FROM THE NORTH-SEA AND THE KATTEGAT', Water Air and Soil Pollution, 56, 283-293.

Jones, R. D., WestThomas, J. and Arfstrom, C. (1997) 'Closed-ampule digestion procedure for the determination of mercury in soil and tissue using cold vapor atomic fluorescence spectrometry', Bulletin of Environmental Contamination and Toxicology, 59(1), 29-34.

Klangsin, P. and Harding, A. K. (1998) 'Medical waste treatment and disposal methods used by hospitals in Oregon, Washington, and Idaho', Journal of the Air \& Waste Management Association, 48(6), 516-526.

Kleypas, J.A. and Yates, K.K. (2009) 'Coral Reefs and Ocean Acidification' Oceanography, vol. 22, 4.

Laake, J., Calambokidis, J. and Osmek, S. (1998) 'Survey report for the 1997 aerial surveys for harbor porpoise and other marine mammals of Oregon, Washington and British Columbia outside waters. Pp. 77-97, In: Hill, P. S., and D.P. DeMaster (eds.), MMPA and ESA Implementation Program, 1997. AFSC Processed Report 98-10. 246 pp. 
Lamborg, C. H., Von Damm, K. L., Fitzgerald, W. F., Hammerschmidt, C. R. and Zierenberg, R. (2006) 'Mercury and monomethylmercury in fluids from Sea Cliff submarine hydrothermal field, Gorda Ridge', Geophysical Research Letters, 33(17), 4.

Le Boeuf, B.J., Crocker, D.E., Costa, D.P., Blackwell, S.B., Webb, P.M. and Houser, D.S. (2000) 'Foraging Ecology of Northern Elephant Seals', Ecological Monographs, 70 (3), 353-382.

Lobring, L. B. and Potter, B. B. (1991) Method 245.6 Determination of mercury in tissues by cold vapor atomic absorption spectrometry.

Lowe, T. P., May, T. W., Brumbaugh, W. G. and Kane, D. A. (1985) 'National Contaminant Biomonitoring Program: concentrations of seven elements in freshwater fish', 14, 363-388.

Lucas, William H. 'Juan de Fuca Ridge and Sovanco Fracture Zone RP-5-OC71' NOAA Technical report ERL 234-POL 11, U.S. Dept of Commerce, (1972)

Manning, R. (2009) 'EPA May Designate Oregon Mercury Mine As Superfund Site', [http:/news.opb.org/article/5875-epa-maydesignate-oregon-mercury-mine-superfund-site/], accessed: November 12, 2009

Merrick, R.L., Brown, R., Calkins, D.G. and Loughlin, T.R. (1995) 'A comparison of Steller sea lion, Eumetopias jubatus, pup masses between rookeries with increasing and decreasing populations', Fishery Bulletin 93, 753-758.

Mieiro, C. L., Pacheco, M., Pereira, M. E. and Duarte, A. C. (2009) 'Mercury distribution in key tissues of fish (Liza aurata) inhabiting a contaminated estuary-implications for human and ecosystem health risk assessment', Journal of Environmental Monitoring, 11(5), 10041012.

Morel, F.M., Kreapiel, A.L.M. and Amyot, M. (1998) 'The chemical cycle and bioaccumulation of mercury', Annual Review of Ecological Systems. 29, 543-566.

NOAA. (2003) Harbor Seal (Phoca vitulina richardsi) Oregon/Washington Coast Stock. www.nmfs.noaa.gov/pr/pdfs/sars/po2003sehr-owco.pdf accessed 2011 
Norton, S. (1986). Toxic responses of the central nervous system. In C.D. Klaassen, M.O. Amdur, and J. Doull (Eds.), Casarett and Doull's Toxicology, third edition, p. 359-386. Macmillan, New York.

Nriagu, J. and Becker, C. (2003) 'Volcanic emissions of mercury to the atmosphere: global and regional inventories', Science of the Total Environment, 304(1-3), 3-12.

Oregon Department of Fish and Wildlife. (2003) California Sea lion Facts www.dfw.state.or.us accessed 2011

Oregon Department of Human Services. (2007) statewide mercury advisories http://www.oregon.gov/DHS/ph/envtox/fishadvisories.shtml, accessed Feb, 2011

Oregon Sea Grant, Sea lions and seals in Oregon, Mate, B. (2003) http://seagrant.oregonstate.edu/sgpubs/onlinepubs/g03013.html, accessed 2011

Pacyna, E.G. and Pacyna, J.M. (2002) 'Global emission of mercury from anthropogenic sources in 1995', Water, Air and Soil Pollution. 137, 149-165.

Park, J. G. and Curtis, L. R. (1997) 'Mercury distribution in sediments and bioaccumulation by fish in two Oregon reservoirs: Point-source and nonpoint-source impacted systems', Archives of Environmental Contamination and Toxicology, 33(4), 423-429.

Pearson, J.P. and Verts, B.J. (1970) 'Abundance and Distribution of Harbor Seals and Northern Sea Lions in Oregon' The Murrelet 1970.

Pitcher, K. W., Olesiuk, P. F., Brown, R. F., Lowry, M. S., Jeffries, S. J., Sease, J. L., Perryman, W. L., Stinchcomb, C. E. and Lowry, L. F. (2007) 'Abundance and distribution of the eastern North Pacific Steller sea lion (Eumetopias jubatus) population', Fishery Bulletin, 105(1), 102-115.

Porcella, D.B. (1994). Mercury in the Environment: Biogeochemistry. In: Watras, C.J., Huckabee, J.W., eds., Lewis Publishers. Mercury Pollution Integration and Synthesis, Boca Raton, Florida. 3-19

Roizin, L., H. Shiraki, and N. Grceric. (1977). NeuroToxicology, Volume 1. Raven Press, New York. 658 pp. 
Read, A.J. (1981) 'Harbor Porpoise Phocoena phocoena', Handbook of marine mammals, Academic Press

Reeves et al., 2002 , R. R., Stewart, B. S., Clapham, P. J. and Powell, J. A. (2002) Guide to marine mammals of the world, New York: Alfred A. Knopf.

Satoh, H. (1995). Toxicological properties and metabolism of mercury; an emphasis on possible method for estimating residual amounts of mercury in the body. In Proceedings of the International Workshop on "Environmental Mercury Pollution and its Health Effects in Amazon River Basin, " p. 106-112, Rio de Janeiro, 30 November-2 December 1994. Published by National Institute for Minimata Disease, Minamata City, Kumamoto 867, Japan.

Schuster, P. F., Krabbenhoft, D. P., Naftz, D. L., Cecil, L. D., Olson, M. L., Dewild, J. F., Susong, D. D., Green, J. R. and Abbott, M. L. (2002) 'Atmospheric mercury deposition during the last 270 years: A glacial ice core record of natural and anthropogenic sources', Environmental Science \& Technology, 36(11), 2303-2310.

Sea World. (2005) Harbor Seals, www.seaworld.org/animal info/harborseal.pdf accessed 2011

Seigneur, C., Vijayaraghavan, K., Lohman, K., Karamchandani, P. and Scott, C. (2004) 'Global source attribution for mercury deposition in the United States', Environmental Science \& Technology, 38(2), 555-569.

Sergeant, D. E. and Armstrong, F. A. J. (1973) 'Mercury in seals from eastern Canada', J. Fish. Res. Board of Canada, 30, 843-846.

Sethajintanin, D., Johnson, E. R., Loper, B. R. and Anderson, K. A. (2004) 'Bioaccumulation profiles of chemical contaminants in fish from the lower Willamette River, Portland Harbor, Oregon', Archives of Environmental Contamination and Toxicology, 46(1), 114-123.

Siebert, U., Joiris, C., Holsbeek, L., Benke, H., Failing, K., Frese, K. and Petzinger, E. (1999) 'Potential relation between mercury concentrations and necropsy findings in cetaceans from German waters of the North and Baltic Seas', Marine Pollution Bulletin, 38(4), 285-295. 
Skelton, H. P. (1925) THE STORAGE OF WATER BY VARIOUS TISSUES $O F T H E B O D Y$, unpublished thesis University of Minnesota.

Smith, T. J. and Armstrong, F. A. J. (1978) 'Mercury and selenium in ringed and bearded seal tissues from Arctic Canada', J. Fish. Res. Board of Canada, 32(2), 75-84.

Szakacs, O., Lasztity, A. and Horvath, Z.S. (1980) 'Breakdown of organic mercury compounds by hydrocloric acid-permanganate or bromine monochloride solution for the determination of mercury by cold vapour atomic absorption spectrometry. Anal Chim Acta 209, 147-156.

Szefer, P. M., Malinga, M., Czarnowsli, W. and Skora, K. (1995) 'Toxic, essential and non-essential metals in harbour porpoises of the Polish Baltic Sea', Whales, Seals, Fish and Man, 617-622.

Tang, S. L., Feng, X. B., Qiu, H. R., Yin, G. X. and Yang, Z. C. (2007) 'Mercury speciation and emissions from coal combustion in Guiyang, southwest China', Environmental Research, 105(2), 175-182.

Tunnicliffe, V., Fowler, C. Mary R., and Mcarthur, Andrew G. (1996) 'Plate tectonic history and hot vent biogeography', Geological Society, v. 118 , p. $225-238$.

Tunnicliffe, V., Botros, M., De Burgh, M.E., Dinet, A., Johnson, H.P., Juniper, S.K. and McDuff, R.E. (1986) 'Hydrothermal vents of Explorer Ridge, northeast Pacific', Deep Sea Research Part A. Oceanographic Research Papers. 33(3), 401-412.

Tupper, A., Carn, S., Davey, J., Kamada, Y., Potts, R., Prata, F. and Tokuno, M. (2004) 'An evaluation of volcanic cloud detection techniques during recent significant eruptions in the western 'Ring of Fire', Remote Sensing of Environment, 91, 27-46.

U.S. EPA. (2001). Fact Sheet: Update: National Listing of Fish and Wildlife Advisories. EPA-823-F-01-010. Office of Water, Washington, DC. http://www.epa.gov/ost/fish/listing.html

Van Delft, W. and Vos, G. (1988) 'Comparison of digestion procedures for the determination of mercury in soils by cold-vapour atomic absorption spectrometry', Anal Chim Acta 209, 147-156. 
Van Dover, Cindy L. (2010) 'Hot Topics: Biogeography of deep-sea hydrothermal vent faunas' Woods Hole Oceanographic Institute www. divediscover.whoi.edu/hottopics/biogeo.html Accessed Jan. 2011

Westgate, A. and Johnson, D. (1995) 'Regional differences in organochlorine and heavy metal contaminants in Western North Atlantic harbour porpoises', International Whaling Commission.

Wright, B., Jeffries, S., Brown, R., Stansell, R., Hatch, D. and Norberg, B. (2007) Field Report -Non-Lethal Pinniped Deterrent Activities at Bonneville Dam, Spring 2006', NOAA field report http://nwr.nmfs.noaa.gov/Marine-Mammals/Seals-and-SeaLions/upload/Bonneville_Pinn_Rpt_06.pdf Accessed Jan. 2011

Zuerner, R. L., Cameron, C. E., Raverty, S., Robinson, J., Colegrove, K. M., Norman, S. A., Lambourn, D., Jeffries, S., Alt, D. P. and Gulland, F. (2009) 'Geographical dissemination of Leptospira interrogans serovar Pomona during seasonal migration of California sea lions', Veterinary Microbiology, 137(1-2), 105-110. 


\section{Appendix A}

\section{Stranding Data for all 105 Samples}

List of individual stranding by Species, Sex, Age, Length (cm), Decomposition code/condition, Locality, and ID. *indicates approximated decomp. Code

\begin{tabular}{|c|c|c|c|c|c|c|}
\hline Sp. & Sex & Age & Length & Decomp/Condition & Locality & ID \\
\hline $\mathrm{Zc}$ & M & adult & 246.4 & 3 , hemorrhaging & Portland, OR & $08-05-06$ \\
\hline $\mathrm{Zc}$ & M & adult & 244 & 3 , shot & Portland, OR & $08-09-23$ \\
\hline $\mathrm{Zc}$ & M & adult & 243 & 3 , lacerations & Cannon Beach, OR & $08-10-05$ \\
\hline $\mathrm{Zc}$ & $\mathrm{m}$ & adult & 243 & 2 , shot & Gearhart, OR & 08-06-17 \\
\hline $\mathrm{Zc}$ & $\mathrm{m}$ & adult & 241 & 3 , bruising & Manzanita, OR & 08-08-20 \\
\hline $\mathrm{Zc}$ & $\mathrm{m}$ & adult & 231.1 & 4, shot & Chinook, WA & $08-11-11$ \\
\hline $\mathrm{Zc}$ & $\mathrm{m}$ & adult & 231 & 4 , Net interaction & Long Beach, WA & 08-09-11 \\
\hline $\mathrm{Zc}$ & $\mathrm{m}$ & adult & 230 & 2 , healthy & Seaside, OR & $08-11-30$ \\
\hline $\mathrm{Zc}$ & $\mathrm{m}$ & adult & 229 & 3 , shot & Seaside, OR & 09-01-09 \\
\hline $\mathrm{Zc}$ & $\mathrm{m}$ & adult & 227.6 & 3 , bruising, thin & Sunset Beach, OR & $07-09-16$ \\
\hline $\mathrm{Zc}$ & $\mathrm{m}$ & adult & 226 & 3 , shot & Del Ray, OR & $08-12-31 B$ \\
\hline $\mathrm{Zc}$ & $\mathrm{m}$ & adult & 225 & 3 , shot & Del Ray, OR & $08-03-14$ \\
\hline $\mathrm{Zc}$ & $\mathrm{m}$ & adult & 222 & 3 , shot & Gearhart, OR & $08-12-23$ \\
\hline $\mathrm{Zc}$ & $\mathrm{m}$ & adult & 221 & 3 , shot & Del Ray, OR & $08-12-31 \mathrm{~A}$ \\
\hline $\mathrm{Zc}$ & $\mathrm{m}$ & adult & 221 & 4 , bruised & Seaside, OR & 08-06-06 \\
\hline $\mathrm{Zc}$ & $\mathrm{m}$ & adult & 218 & 2 , lots of fluid & Sunset Beach, OR & 08-06-09 \\
\hline $\mathrm{Zc}$ & $\mathrm{m}$ & adult & 218 & 2 , shot & Tierra del mar, OR & $07-10-25$ \\
\hline $\mathrm{Zc}$ & $\mathrm{m}$ & adult & 216 & 3 , shot & Gearhart, OR & $08-12-31 \mathrm{C}$ \\
\hline $\mathrm{Zc}$ & $\mathrm{m}$ & adult & 215 & 2 , shot & Gearhart, OR & $08-12-14 \mathrm{~A}$ \\
\hline $\mathrm{Zc}$ & $\mathrm{m}$ & adult & 210 & 4 , bruised & Gearhart, OR & 09-01-04A \\
\hline $\mathrm{Zc}$ & $\mathrm{m}$ & adult & 210 & 2, shot & Seaside, OR & $08-12-16$ \\
\hline $\mathrm{Zc}$ & $\mathrm{m}$ & adult & 209 & 4, good & Warrenton, OR & 09-01-03 \\
\hline $\mathrm{Zc}$ & $\mathrm{m}$ & adult & 203 & 3 , hooked & Tierra del mar, OR & $08-06-15$ \\
\hline $\mathrm{Zc}$ & $\mathrm{m}$ & adult & 187 & 3 , rope marks & Long Beach, WA & $08-11-28$ \\
\hline $\mathrm{Zc}$ & $\mathrm{m}$ & adult & 169.5 & 2 , infection & Astoria, OR & $07-11-06$ \\
\hline $\mathrm{Zc}$ & $\mathrm{m}$ & sub-adult & 193 & 2 , net & Ilwaco, WA & 08-08-18 \\
\hline $\mathrm{Zc}$ & $\mathrm{m}$ & sub-adult & 185.4 & 2 , emaciated & Seaview, WA & $08-09-24$ \\
\hline $\mathrm{Zc}$ & $\mathrm{m}$ & sub-adult & 152.4 & 2 , bruising & Seaview, WA & $08-10-02$ \\
\hline $\mathrm{Zc}$ & $\mathrm{m}$ & sub-adult & 91 & 2, nose smashed & Warrenton, OR & 09-01-11 \\
\hline $\mathrm{Zc}$ & $\mathrm{f}$ & sub-adult & 122.7 & 3 , neck trauma & Seaside, OR & $08-03-26$ \\
\hline $\mathrm{Zc}$ & $?$ & unknown & 209.4 & 5 , skeletal & Gearhart, OR & 09-01-04B \\
\hline $\mathrm{Pv}$ & $\mathrm{m}$ & adult & 149 & 3 , wedged fetus & Pacific City, OR & $08-05-10$ \\
\hline $\mathrm{Pv}$ & $\mathrm{m}$ & adult & 146 & 4 , skull crushed & Ilwaco, WA & 07-04-01A \\
\hline $\mathrm{Pv}$ & $\mathrm{m}$ & adult & 140.5 & 3 , bruising & Warrenton, OR & $07-10-01$ \\
\hline $\mathrm{Pv}$ & $\mathrm{m}$ & adult & 137 & 2, Congested & Cannon Beach, OR & $08-06-30$ \\
\hline $\mathrm{Pv}$ & $\mathrm{m}$ & adult & 131 & 4 , none & Long Beach, WA & $08-03-14$ \\
\hline $\mathrm{Pv}$ & $\mathrm{m}$ & adult & 129.4 & 3 , collapsed lung & Warrenton, OR & 07-06-11 \\
\hline $\mathrm{Pv}$ & $\mathrm{m}$ & adult & 129 & 2, shark bite & Seaside, OR & $07-10-12$ \\
\hline
\end{tabular}




\begin{tabular}{|c|c|c|c|c|c|c|}
\hline $\mathrm{Pv}$ & $\mathrm{m}$ & adult & 120.9 & 2 , very thin & Garibaldi, OR & $07-06-02$ \\
\hline $\mathrm{Pv}$ & $\mathrm{f}$ & adult & 142 & 4 , shot & Rockaway, OR & $08-10-14$ \\
\hline $\mathrm{Pv}$ & $\mathrm{f}$ & adult & 141 & 2, hemorrhaging & Gearhart, OR & $06-07-13$ \\
\hline $\mathrm{Pv}$ & $\mathrm{f}$ & sub-adult & 150 & 3 , meningoencep.* & Lakeside, OR & $07-04-16$ \\
\hline $\mathrm{Pv}$ & $\mathrm{f}$ & sub-adult & 129 & 2 , none taken & Ocean Park, WA & 08-09-09 \\
\hline $\mathrm{Pv}$ & $\mathrm{f}$ & sub-adult & 126 & 3 , bruising, good & Del Ray, OR & $07-07-07$ \\
\hline $\mathrm{Pv}$ & $\mathrm{f}$ & sub-adult & 120.9 & 4 , bruising & Del Ray, OR & 07-10-05 \\
\hline $\mathrm{Pv}$ & $\mathrm{f}$ & sub-adult & 94 & 3 , severe bruising & Cannon Beach, OR & $08-03-16$ \\
\hline $\mathrm{Pv}$ & $\mathrm{f}$ & pup/calf & 69.5 & 2, bloody head & Long Beach, WA & 07-04-27A \\
\hline $\mathrm{Pv}$ & $\mathrm{f}$ & pup/calf & 59.5 & 1, umbilicus att. & Seaview, WA & 07-04-27B \\
\hline $\mathrm{Pv}$ & $?$ & yearling & 90.2 & 2 , extensive bleed & Seaside, OR & 08-04-07 \\
\hline $\mathrm{Pp}$ & $\mathrm{m}$ & adult & 149 & 3 , none & Gearhart, OR & $04-05-12$ \\
\hline $\mathrm{Pp}$ & $\mathrm{m}$ & adult & 148 & 3 , shark bites & Long Beach, WA & 07-05-11B \\
\hline $\mathrm{Pp}$ & $\mathrm{m}$ & adult & 143.6 & 3 , puncture wound & Del Ray, OR & 07-07-19 \\
\hline $\mathrm{Pp}$ & $\mathrm{m}$ & adult & 137.2 & 4, ext. bruising & Arch Cape, OR & 07-08-30 \\
\hline $\mathrm{Pp}$ & $\mathrm{m}$ & adult & 0 & 4, bloody abd. & Long Beach, WA & $07-04-28$ \\
\hline $\mathrm{Pp}$ & $\mathrm{m}$ & sub-adult & 137 & 3 , none & Seaside, OR & 04-04-08 \\
\hline $\mathrm{Pp}$ & $\mathrm{m}$ & sub-adult & 135 & 2, worm infection & Del Ray, OR & $07-07-15$ \\
\hline $\mathrm{Pp}$ & $\mathrm{m}$ & sub-adult & 126 & 4, hemorrhaging & Seaview, WA & $07-05-11 \mathrm{~A}$ \\
\hline $\mathrm{Pp}$ & $\mathrm{m}$ & sub-adult & 123.3 & 3 , rndwrms, flukes & Warrenton, OR & 06-03-04 \\
\hline $\mathrm{Pp}$ & $\mathrm{m}$ & sub-adult & 118.5 & 3 , emaciated & Del Ray, OR & 07-06-13 \\
\hline $\mathrm{Pp}$ & $\mathrm{m}$ & sub-adult & 98.5 & 3 , cuts & Sunset Beach, OR & $07-10-19$ \\
\hline $\mathrm{Pp}$ & $\mathrm{m}$ & yearling & 127.5 & 2 , none & Seaside, OR & 08-04-14 \\
\hline $\mathrm{Pp}$ & $\mathrm{f}$ & adult & 110.8 & 4, thorax bruising & Sunset Beach, OR & $07-10-05$ \\
\hline $\mathrm{Pp}$ & $\mathrm{f}$ & yearling & 113 & 3 , abrasions & Seaside, OR & 07-04-30 \\
\hline $\mathrm{Pp}$ & $\mathrm{f}$ & yearling & 93.7 & 2 , very emaciated & Pacific City, OR & $07-08-20$ \\
\hline $\mathrm{Pp}$ & $\mathrm{f}$ & yearling & 92.3 & 3 , rope marks & Ilwaco, WA & 07-08-05 \\
\hline $\mathrm{Pp}$ & $\mathrm{f}$ & yearling & 66 & 3 , none & Long Beach, WA & $06-07-22$ \\
\hline $\mathrm{Pp}$ & $\mathrm{f}$ & adult & 146.2 & 3 , none & Seaside, OR & 04-06-06 \\
\hline $\mathrm{Pp}$ & $\mathrm{f}$ & adult & 0 & 3 , lacerations & $?$ & $02-09-26$ \\
\hline $\mathrm{Pp}$ & $?$ & sub-adult & 128.2 & 3 , fresh, shark bites & Seaside, OR & 06-07-18 \\
\hline $\mathrm{Pp}$ & $?$ & none & 94 & 3 , none & Manzanita, OR & $08-09-26$ \\
\hline $\mathrm{Ma}$ & $\mathrm{m}$ & adult & 278 & 4, ext. bruising & Manzanita, OR & $08-08-21$ \\
\hline Ma & $\mathrm{m}$ & yearling & 158 & 2, bloody head & Del Ray, OR & 07-09-05 \\
\hline Ma & $\mathrm{m}$ & yearling & 141 & 3,5 broken ribs & Pacific City, OR & $08-08-15 B$ \\
\hline Ма & $\mathrm{m}$ & yearling & 138.4 & 1 , lesions & Cannon Beach, OR & $08-10-14$ \\
\hline Ma & $\mathrm{m}$ & pup/calf & 159 & 3 , heart worm* & Newport, OR & $07-06-22$ \\
\hline $\mathrm{Ma}$ & $\mathrm{m}$ & pup/calf & 147.6 & 3, thin* & Newport, OR & 07-07-19 \\
\hline Ma & $\mathrm{f}$ & yearling & 155 & 3 , ext. bruising & Manzanita, OR & $08-08-15 \mathrm{~A}$ \\
\hline $\mathrm{Ma}$ & $\mathrm{f}$ & yearling & 142 & 1, skin ulcerations & Cannon Beach, OR & 08-05-07 \\
\hline $\mathrm{Ej}$ & $\mathrm{m}$ & adult & 292.1 & 4 , massive bruising & Arcadia, OR & $08-07-23$ \\
\hline $\mathrm{Ej}$ & $\mathrm{m}$ & adult & 285 & 3, good, w. hemorr. & Rockaway, OR & $08-05-13$ \\
\hline $\mathrm{Ej}$ & $\mathrm{m}$ & adult & 282 & 4 , shot & Warrenton, OR & $08-06-25$ \\
\hline $\mathrm{Ej}$ & $\mathrm{m}$ & adult & 281 & 4 , bruising & Garibaldi, OR & 08-08-04 \\
\hline $\mathrm{Ej}$ & $\mathrm{m}$ & adult & 280 & 3 , none* & Yachats, OR & 06-08-17 \\
\hline $\mathrm{Ej}$ & $\mathrm{m}$ & adult & 273 & 4, dorsal bruising & Tierra del mar, OR & $08-06-15$ \\
\hline
\end{tabular}




\begin{tabular}{|c|c|c|c|c|c|c|}
\hline $\mathrm{Ej}$ & $\mathrm{m}$ & adult & 270 & 3 , bruising & Ilwaco, WA & $07-02-15$ \\
\hline $\mathrm{Ej}$ & $\mathrm{m}$ & yearling & 146 & 3, none* & Heceta Beach, OR & $07-05-11$ \\
\hline $\mathrm{Ej}$ & $\mathrm{m}$ & yearling & 138 & 3, leptospirosis* & Florence, OR & $07-05-10$ \\
\hline $\mathrm{Ej}$ & $\mathrm{m}$ & yearling & 122 & 4 , skull fracture & Del Ray, OR & $08-05-10$ \\
\hline $\mathrm{Ej}$ & $\mathrm{f}$ & adult & 243 & 3, flks, pos. herp.* & Bandon, OR & $07-02-05$ \\
\hline $\mathrm{Ej}$ & $\mathrm{f}$ & adult & 231 & 4 , W/full term fetus & Long Beach, WA & $07-05-21$ \\
\hline $\mathrm{Ej}$ & $\mathrm{f}$ & adult & 230 & 4, emaciated & Oysterville, WA & $06-10-27$ \\
\hline $\mathrm{Ej}$ & $\mathrm{f}$ & adult & 227 & 3 , bruising & Long Beach, WA & $08-11-28$ \\
\hline $\mathrm{Ej}$ & $\mathrm{f}$ & adult & 225 & 3 , ext. bruising & Long Beach, WA & $08-03-11$ \\
\hline $\mathrm{Ej}$ & $\mathrm{f}$ & adult & 221 & 4 , none & Cape Mears, OR & $08-08-10 \mathrm{~A}$ \\
\hline $\mathrm{Ej}$ & $\mathrm{f}$ & adult & 214.6 & 3 , mummified fetus & Cannon Beach, OR & 08-07-30 \\
\hline $\mathrm{Ej}$ & $\mathrm{f}$ & adult & 211 & 3 , emaciated & Seaside, OR & $08-09-20$ \\
\hline $\mathrm{Ej}$ & $\mathrm{f}$ & adult & 210 & 3, diaphram cancer & Sunset Beach, OR & 08-04-10 \\
\hline $\mathrm{Ej}$ & $\mathrm{f}$ & adult & 209 & 3 , ext. bruising & Warrenton, OR & 08-06-09 \\
\hline EJ & $\mathrm{f}$ & adult & 203.2 & 4 , stomach ulcers & Del Ray, OR & $08-11-25$ \\
\hline $\mathrm{Ej}$ & $\mathrm{f}$ & adult & 203 & 3 , liver lumps & Tillamook, OR & 08-06-02 \\
\hline $\mathrm{Ej}$ & $\mathrm{f}$ & adult & 172 & 2, large shark bite & Warrenton, OR & 07-06-10 \\
\hline $\mathrm{Ej}$ & $\mathrm{f}$ & sub-adult & 215 & 3 , liver parasites* & Ona beach, OR & $06-10-16$ \\
\hline $\mathrm{Ej}$ & $\mathrm{f}$ & sub-adult & 194.5 & 2 , emaciated & Rockaway, OR & $08-05-23$ \\
\hline Ej & $\mathrm{f}$ & sub-adult & 191 & 4 , scavenged* & Yachats, OR & 07-04-10 \\
\hline $\mathrm{Ej}$ & $\mathrm{f}$ & sub-adult & 147 & 3 , pneumonia* & Florence, OR & $07-01-26$ \\
\hline
\end{tabular}




\section{Appendix B}

\section{THg Concentrations of 105 Muscle Samples}

Species, sex, ID, ppm ww, ppm dw, ppm normalized, \& $\% \mathrm{H}_{2} \mathrm{O}$ from all 105 samples. ID is in the format of Year/Month/Day.

\begin{tabular}{|c|c|c|c|c|c|c|}
\hline sp. & Sex & ID & ppm ww & ppm dw & ppm norm. & $\% \mathrm{H}_{2} \mathrm{O}$ \\
\hline $\mathrm{Zc}$ & $\mathrm{m}$ & 09-01-11 & 0.25 & 0.45 & 0.07 & 0.437 \\
\hline $\mathrm{Zc}$ & $\mathrm{m}$ & 09-01-09 & 0.20 & 0.51 & 0.10 & 0.609 \\
\hline $\mathrm{Zc}$ & $\mathrm{m}$ & 09-01-04B & 0.18 & 0.37 & 0.06 & 0.498 \\
\hline $\mathrm{Zc}$ & $\mathrm{m}$ & 09-01-04A & 0.00 & 0.00 & 0.00 & 0.607 \\
\hline $\mathrm{Zc}$ & $\mathrm{m}$ & 09-01-03 & 0.45 & 0.84 & 0.13 & 0.470 \\
\hline $\mathrm{Zc}$ & $\mathrm{m}$ & $08-12-31 \mathrm{C}$ & 0.18 & 0.32 & 0.05 & 0.442 \\
\hline $\mathrm{Zc}$ & $\mathrm{m}$ & 08-12-31B & 0.22 & 0.42 & 0.07 & 0.474 \\
\hline $\mathrm{Zc}$ & $\mathrm{m}$ & 08-12-31A & 0.62 & 1.42 & 0.27 & 0.562 \\
\hline $\mathrm{Zc}$ & $\mathrm{m}$ & $08-12-23$ & 0.71 & 1.30 & 0.20 & 0.459 \\
\hline $\mathrm{Zc}$ & $\mathrm{m}$ & $08-12-16$ & 1.16 & 1.96 & 0.27 & 0.410 \\
\hline $\mathrm{Zc}$ & $\mathrm{m}$ & $08-12-14 \mathrm{~A}$ & 0.66 & 1.02 & 0.12 & 0.356 \\
\hline $\mathrm{Zc}$ & $\mathrm{m}$ & 08-11-30 & 1.06 & 1.75 & 0.23 & 0.392 \\
\hline $\mathrm{Zc}$ & $\mathrm{m}$ & $08-11-28$ & 0.60 & 1.01 & 0.13 & 0.402 \\
\hline $\mathrm{Zc}$ & $\mathrm{m}$ & 08-11-11 & 0.44 & 0.73 & 0.10 & 0.396 \\
\hline $\mathrm{Zc}$ & $\mathrm{m}$ & $08-10-05$ & 0.18 & 0.34 & 0.05 & 0.465 \\
\hline $\mathrm{Zc}$ & $\mathrm{m}$ & 08-10-02 & 1.14 & 2.02 & 0.29 & 0.436 \\
\hline $\mathrm{Zc}$ & $\mathrm{m}$ & 08-09-24 & 0.41 & 0.74 & 0.11 & 0.441 \\
\hline $\mathrm{Zc}$ & $\mathrm{m}$ & $08-09-23$ & 0.64 & 1.48 & 0.28 & 0.565 \\
\hline $\mathrm{Zc}$ & $\mathrm{m}$ & 08-09-11 & 0.46 & 0.85 & 0.13 & 0.462 \\
\hline $\mathrm{Zc}$ & $\mathrm{m}$ & 08-08-20 & 0.66 & 1.07 & 0.14 & 0.383 \\
\hline $\mathrm{Zc}$ & $\mathrm{m}$ & 08-08-18 & 0.57 & 0.89 & 0.11 & 0.358 \\
\hline $\mathrm{Zc}$ & $\mathrm{m}$ & 08-06-17 & 0.49 & 0.78 & 0.10 & 0.373 \\
\hline $\mathrm{Zc}$ & $\mathrm{m}$ & 08-06-15 & 0.34 & 0.80 & 0.15 & 0.574 \\
\hline $\mathrm{Zc}$ & $\mathrm{m}$ & 08-06-09 & 0.30 & 0.87 & 0.19 & 0.654 \\
\hline $\mathrm{Zc}$ & $\mathrm{m}$ & 08-06-06 & 1.62 & 3.47 & 0.62 & 0.534 \\
\hline $\mathrm{Zc}$ & $\mathrm{m}$ & 08-05-06 & 1.93 & 7.41 & 1.19 & 0.339 \\
\hline $\mathrm{Zc}$ & $\mathrm{f}$ & $08-03-26$ & 0.16 & 0.29 & 0.04 & 0.455 \\
\hline $\mathrm{Zc}$ & $\mathrm{m}$ & 08-03-14 & 0.98 & 2.17 & 0.40 & 0.549 \\
\hline $\mathrm{Zc}$ & $\mathrm{m}$ & 07-11-06 & 0.12 & 0.20 & 0.03 & 0.414 \\
\hline $\mathrm{Zc}$ & $\mathrm{m}$ & $07-10-25$ & 0.67 & 1.17 & 0.17 & 0.431 \\
\hline $\mathrm{Zc}$ & $\mathrm{m}$ & 07-09-16 & 0.13 & 0.22 & 0.03 & 0.423 \\
\hline $\mathrm{Pv}$ & $\mathrm{f}$ & 07-04-16 & 1.74 & 3.10 & 0.45 & 0.439 \\
\hline $\mathrm{Pv}$ & $\mathrm{f}$ & $08-10-14$ & 0.23 & 0.44 & 0.07 & 0.492 \\
\hline $\mathrm{Pv}$ & $\mathrm{f}$ & 08-09-09 & 0.74 & 1.37 & 0.21 & 0.462 \\
\hline $\mathrm{Pv}$ & $\mathrm{m}$ & 08-06-30 & 1.09 & 2.07 & 0.33 & 0.474 \\
\hline $\mathrm{Pv}$ & $\mathrm{m}$ & $08-05-10$ & 1.03 & 2.47 & 0.48 & 0.584 \\
\hline
\end{tabular}




\begin{tabular}{|c|c|l|c|c|c|c|}
\hline $\mathrm{Pv}$ & $?$ & $08-04-07$ & 0.77 & 1.22 & 0.15 & 0.370 \\
\hline $\mathrm{Pv}$ & $\mathrm{f}$ & $08-03-16$ & 0.74 & 1.29 & 0.18 & 0.426 \\
\hline $\mathrm{Pv}$ & $\mathrm{m}$ & $08-03-14$ & 0.89 & 1.41 & 0.17 & 0.367 \\
\hline $\mathrm{Pv}$ & $\mathrm{m}$ & $07-10-12$ & 0.86 & 1.63 & 0.26 & 0.473 \\
\hline $\mathrm{Pv}$ & $\mathrm{f}$ & $07-10-05$ & 0.11 & 0.26 & 0.05 & 0.581 \\
\hline $\mathrm{Pv}$ & $\mathrm{m}$ & $07-10-01$ & 0.54 & 0.83 & 0.10 & 0.352 \\
\hline $\mathrm{Pv}$ & $\mathrm{f}$ & $07-07-07$ & 0.43 & 0.71 & 0.09 & 0.389 \\
\hline $\mathrm{Pv}$ & $\mathrm{m}$ & $07-06-11$ & 1.73 & 4.41 & 0.90 & 0.609 \\
\hline $\mathrm{Pv}$ & $\mathrm{m}$ & $07-06-02$ & 0.66 & 1.05 & 0.13 & 0.369 \\
\hline $\mathrm{Pv}$ & $\mathrm{f}$ & $07-04-27 \mathrm{~B}$ & 0.11 & 0.17 & 0.02 & 0.364 \\
\hline $\mathrm{Pv}$ & $\mathrm{f}$ & $07-04-27 \mathrm{~A}$ & 0.22 & 0.35 & 0.04 & 0.380 \\
\hline $\mathrm{Pv}$ & $\mathrm{m}$ & $07-04-01 \mathrm{~A}$ & 0.65 & 1.14 & 0.16 & 0.430 \\
\hline $\mathrm{Pv}$ & $\mathrm{f}$ & $06-07-13$ & 0.28 & 0.50 & 0.07 & 0.444 \\
\hline $\mathrm{Pp}$ & $?$ & $08-09-26$ & 0.05 & 0.13 & 0.02 & 0.574 \\
\hline $\mathrm{Pp}$ & $\mathrm{m}$ & $08-04-14$ & 0.19 & 0.35 & 0.06 & 0.469 \\
\hline $\mathrm{Pp}$ & $\mathrm{m}$ & $07-10-19$ & 0.29 & 0.44 & 0.05 & 0.328 \\
\hline $\mathrm{Pp}$ & $\mathrm{f}$ & $07-10-05$ & 0.22 & 0.33 & 0.04 & 0.337 \\
\hline $\mathrm{Pp}$ & $\mathrm{m}$ & $07-08-30$ & 1.02 & 1.96 & 0.32 & 0.481 \\
\hline $\mathrm{Pp}$ & $\mathrm{f}$ & $07-08-20$ & 0.64 & 1.15 & 0.17 & 0.445 \\
\hline $\mathrm{Pp}$ & $\mathrm{f}$ & $07-08-05$ & 0.73 & 1.18 & 0.15 & 0.383 \\
\hline $\mathrm{Pp}$ & $\mathrm{m}$ & $07-07-19$ & 1.16 & 2.19 & 0.34 & 0.469 \\
\hline $\mathrm{Pp}$ & $\mathrm{m}$ & $07-07-15$ & 1.65 & 3.16 & 0.50 & 0.477 \\
\hline $\mathrm{Pp}$ & $\mathrm{m}$ & $07-06-13$ & 0.46 & 0.89 & 0.14 & 0.482 \\
\hline $\mathrm{Pp}$ & $\mathrm{m}$ & $07-05-11 \mathrm{~B}$ & 0.65 & 1.26 & 0.20 & 0.479 \\
\hline $\mathrm{Pp}$ & $\mathrm{m}$ & $07-05-11 \mathrm{~A}$ & 0.47 & 0.83 & 0.12 & 0.430 \\
\hline $\mathrm{Pp}$ & $\mathrm{f}$ & $07-04-30$ & 0.74 & 1.49 & 0.25 & 0.507 \\
\hline $\mathrm{Pp}$ & $\mathrm{m}$ & $07-04-28$ & 0.09 & 0.16 & 0.02 & 0.433 \\
\hline $\mathrm{Pp}$ & $\mathrm{f}$ & $06-07-22$ & 0.18 & 0.32 & 0.05 & 0.458 \\
\hline $\mathrm{Pp}$ & $?$ & $06-07-18$ & 0.12 & 0.23 & 0.02 & 0.323 \\
\hline $\mathrm{Pp}$ & $\mathrm{m}$ & $06-03-04$ & 0.50 & 0.96 & 0.15 & 0.475 \\
\hline $\mathrm{Pp}$ & $\mathrm{f}$ & $04-06-06$ & 1.12 & 3.15 & 0.67 & 0.643 \\
\hline $\mathrm{Pp}$ & $\mathrm{m}$ & $04-05-12$ & 0.79 & 1.33 & 0.18 & 0.406 \\
\hline $\mathrm{Pp}$ & $\mathrm{m}$ & $04-04-08$ & 0.65 & 1.07 & 0.14 & 0.388 \\
\hline $\mathrm{Pp}$ & $\mathrm{f}$ & $02-09-26$ & 0.06 & 0.10 & 0.01 & 0.363 \\
\hline $\mathrm{Ma}$ & $\mathrm{m}$ & $07-07-19$ & 0.16 & 0.32 & 0.05 & 0.497 \\
\hline $\mathrm{Ma}$ & $\mathrm{m}$ & $07-06-22$ & 0.66 & 1.10 & 0.14 & 0.395 \\
\hline $\mathrm{Ma}$ & $\mathrm{m}$ & $08-10-14$ & 0.51 & 1.19 & 0.22 & 0.567 \\
\hline $\mathrm{Ma}$ & $\mathrm{m}$ & $08-08-21$ & 2.86 & 7.37 & 1.50 & 0.612 \\
\hline $\mathrm{Ma}$ & $\mathrm{m}$ & $08-08-15 \mathrm{~B}$ & 0.28 & 0.53 & 0.08 & 0.474 \\
\hline $\mathrm{f}$ & $\mathrm{f}$ & $08-08-15 \mathrm{~A}$ & 0.21 & 0.33 & 0.04 & 0.376 \\
\hline $\mathrm{M}$ & $07-09-07$ & 1.76 & 3.05 & 0.43 & 0.422 \\
\hline
\end{tabular}




\begin{tabular}{|c|c|l|c|c|c|c|}
\hline $\mathrm{Ej}$ & $\mathrm{m}$ & $07-05-10$ & 0.05 & 0.07 & 0.01 & 0.294 \\
\hline $\mathrm{Ej}$ & $\mathrm{f}$ & $07-04-10$ & 0.40 & 0.74 & 0.11 & 0.456 \\
\hline $\mathrm{Ej}$ & $\mathrm{f}$ & $07-02-05$ & 1.24 & 2.30 & 0.35 & 0.461 \\
\hline $\mathrm{Ej}$ & $\mathrm{f}$ & $07-01-26$ & 0.25 & 0.43 & 0.06 & 0.423 \\
\hline $\mathrm{Ej}$ & $\mathrm{f}$ & $06-10-16$ & 0.79 & 1.94 & 0.39 & 0.595 \\
\hline $\mathrm{Ej}$ & $\mathrm{m}$ & $06-08-17$ & 0.63 & 1.33 & 0.23 & 0.525 \\
\hline $\mathrm{Ej}$ & $\mathrm{f}$ & $08-11-28$ & 1.22 & 2.13 & 0.30 & 0.424 \\
\hline $\mathrm{Ej}$ & $\mathrm{f}$ & $08-11-25$ & 1.64 & 3.02 & 0.46 & 0.458 \\
\hline $\mathrm{Ej}$ & $\mathrm{f}$ & $08-09-20$ & 1.70 & 2.64 & 0.31 & 0.357 \\
\hline $\mathrm{Ej}$ & $\mathrm{f}$ & $08-08-10 \mathrm{~A}$ & 1.11 & 1.86 & 0.25 & 0.403 \\
\hline $\mathrm{Ej}$ & $\mathrm{m}$ & $08-08-04$ & 1.17 & 2.13 & 0.32 & 0.453 \\
\hline $\mathrm{Ej}$ & $\mathrm{f}$ & $08-07-30$ & 1.50 & 2.78 & 0.43 & 0.462 \\
\hline $\mathrm{Ej}$ & $\mathrm{m}$ & $08-07-23$ & 0.76 & 1.17 & 0.14 & 0.349 \\
\hline $\mathrm{Ej}$ & $\mathrm{m}$ & $08-06-25$ & 2.19 & 5.60 & 1.14 & 0.609 \\
\hline $\mathrm{Ej}$ & $\mathrm{m}$ & $08-06-15$ & 1.11 & 3.40 & 0.77 & 0.675 \\
\hline $\mathrm{Ej}$ & $\mathrm{f}$ & $08-06-09$ & 1.13 & 2.15 & 0.34 & 0.475 \\
\hline $\mathrm{Ej}$ & $\mathrm{f}$ & $08-06-02$ & 0.19 & 0.35 & 0.05 & 0.455 \\
\hline $\mathrm{Ej}$ & $\mathrm{f}$ & $08-05-23$ & 1.73 & 2.85 & 0.37 & 0.394 \\
\hline $\mathrm{Ej}$ & $\mathrm{m}$ & $08-05-13$ & 1.91 & 3.35 & 0.48 & 0.430 \\
\hline $\mathrm{EJ}$ & $\mathrm{m}$ & $08-05-10$ & 0.09 & 0.13 & 0.02 & 0.359 \\
\hline $\mathrm{Ej}$ & $\mathrm{f}$ & $08-04-10$ & 3.73 & 5.94 & 0.74 & 0.372 \\
\hline $\mathrm{Ej}$ & $\mathrm{f}$ & $08-03-11$ & 4.13 & 6.80 & 0.89 & 0.393 \\
\hline $\mathrm{Ej}$ & $\mathrm{f}$ & $07-06-10$ & 1.49 & 2.46 & 0.32 & 0.394 \\
\hline $\mathrm{Ej}$ & $\mathrm{f}$ & $07-05-21$ & 0.29 & 0.57 & 0.09 & 0.486 \\
\hline $\mathrm{Ej}$ & $\mathrm{m}$ & $07-02-15$ & 2.14 & 3.46 & 0.44 & 0.381 \\
\hline $\mathrm{Ej}$ & $\mathrm{f}$ & $06-10-27$ & 0.95 & 1.61 & 0.22 & 0.410 \\
\hline & & & & & & \\
\hline
\end{tabular}




\section{Appendix C}

\section{Box and Whisker Plots}

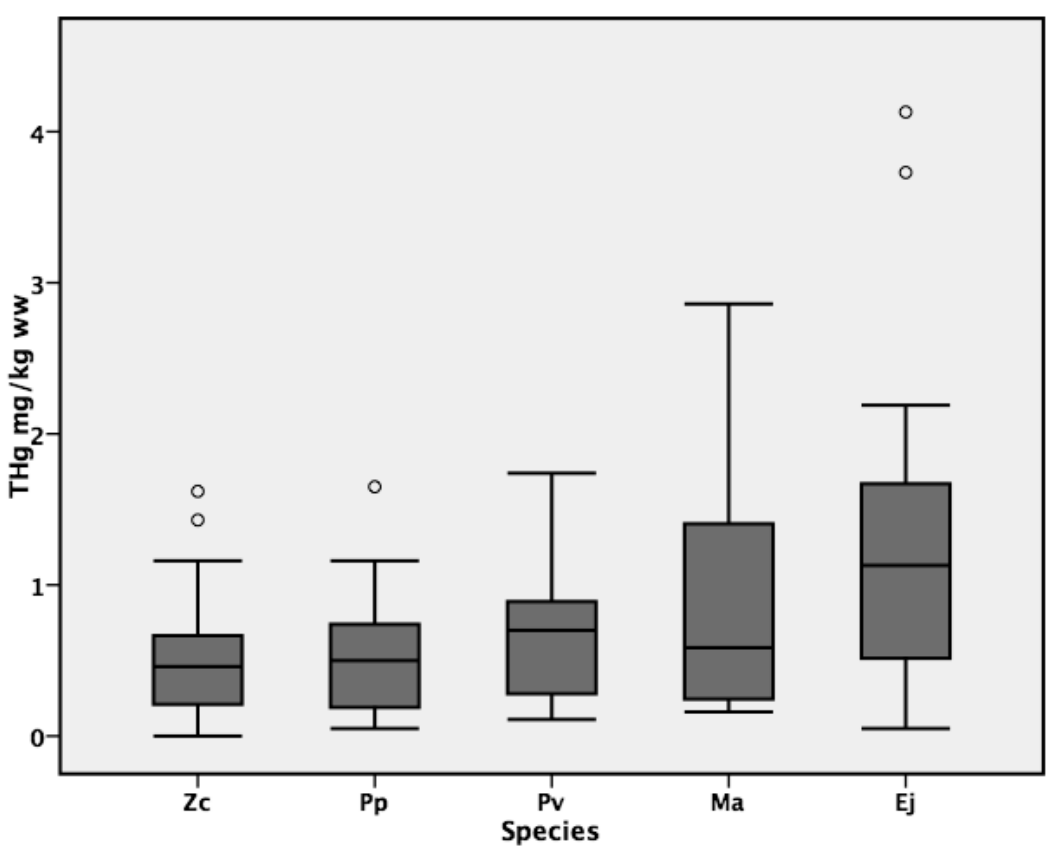

A-Box and whisker plot of $\mathrm{THg}$ ( $\mathrm{mg} / \mathrm{kg}$ muscle wet weight).

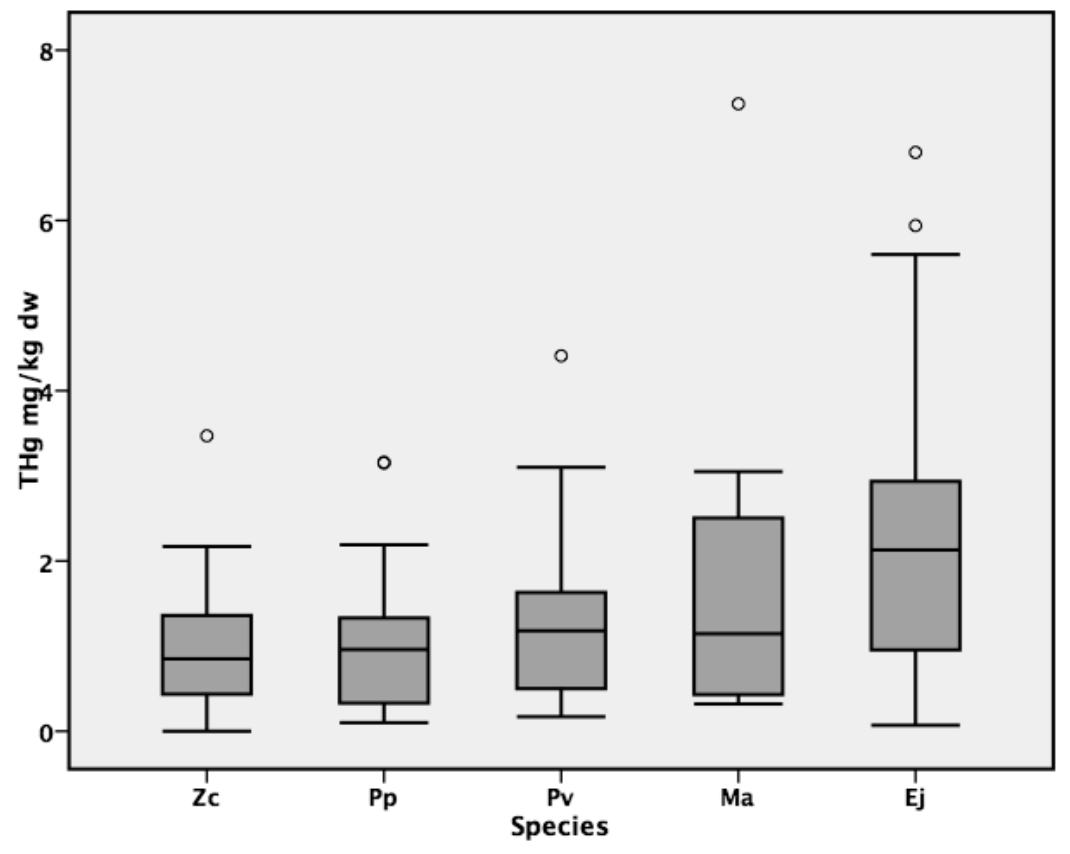

B-Box and whisker plot of $\mathrm{THg}$ ( $\mathrm{mg} / \mathrm{kg}$ muscle dry weight) 


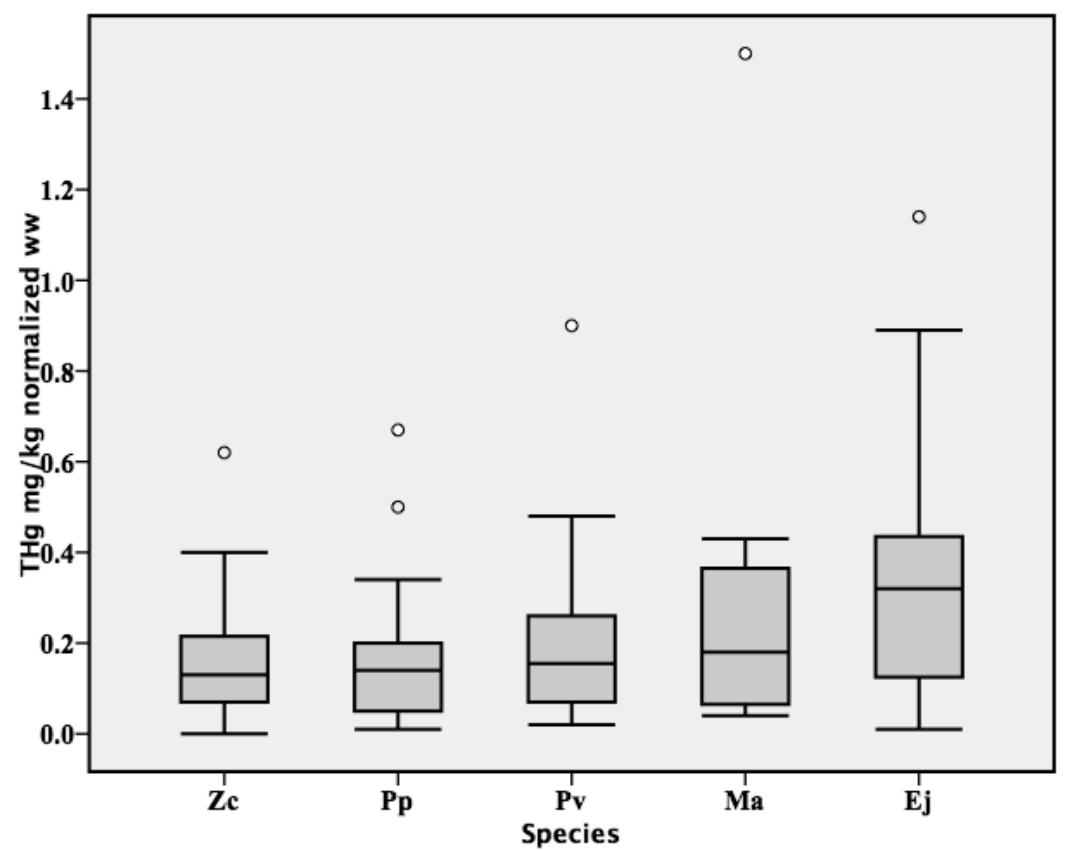

C-Box and whisker plot of $\mathrm{THg}(\mathrm{mg} / \mathrm{kg}$ muscle normalized weight) 


\section{Appendix D}

\section{Log Transformed THg Concentrations}

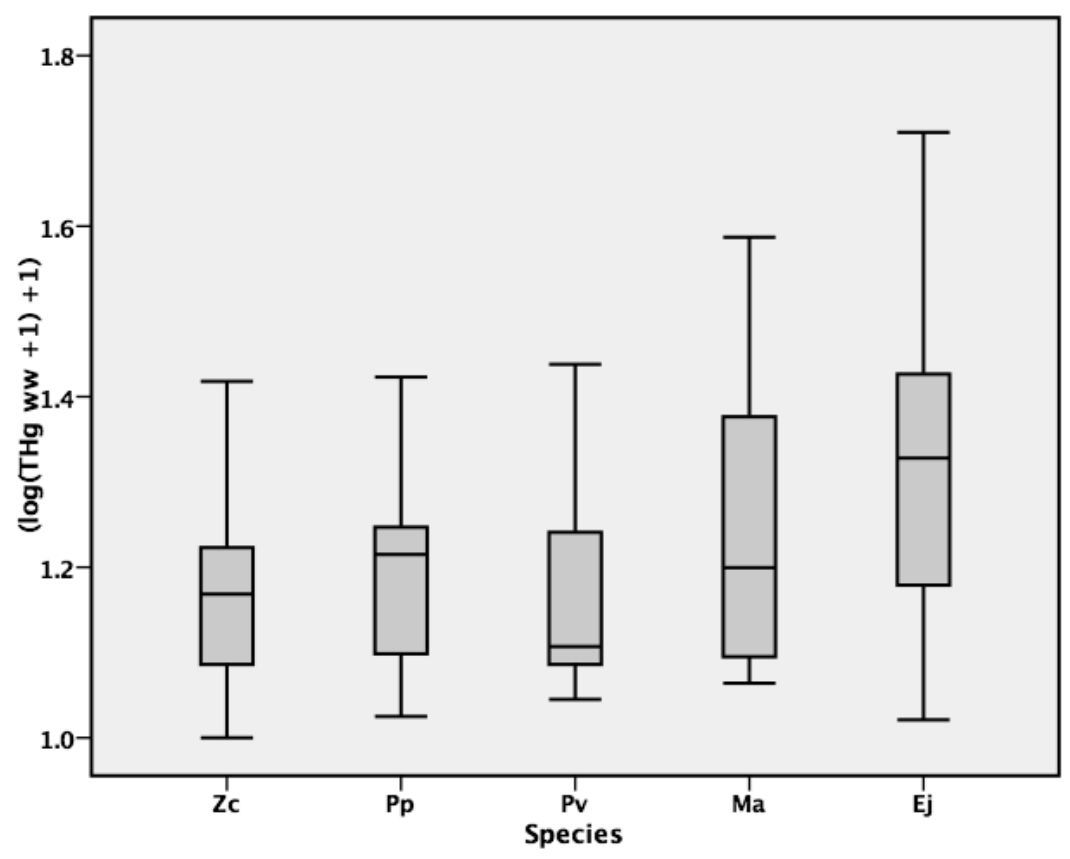

Box and whisker plot showing the distribution of $\mathrm{THg}$ from each species. $\mathrm{THg}$ was log transformed $(\log (\mathrm{THg} w \mathrm{w}+1)+1)$, to normalize. 


\section{Appendix E}

\section{Species Linear Regression}

Graphs (A-E)- THg ww vs. length $(\mathrm{cm})$, square $=$ male , circle $=$ female , triangle $=$ unknown sex. Linear regression with $\mathrm{R}$-square value in top left hand corner.

A- California sea lion

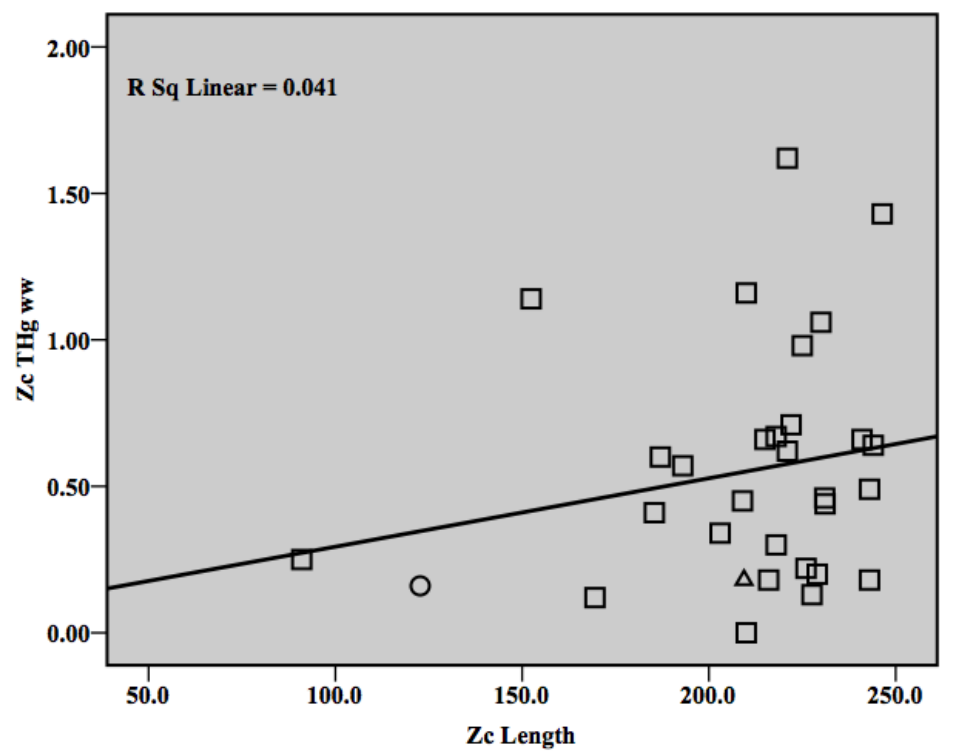

B- Harbor porpoise

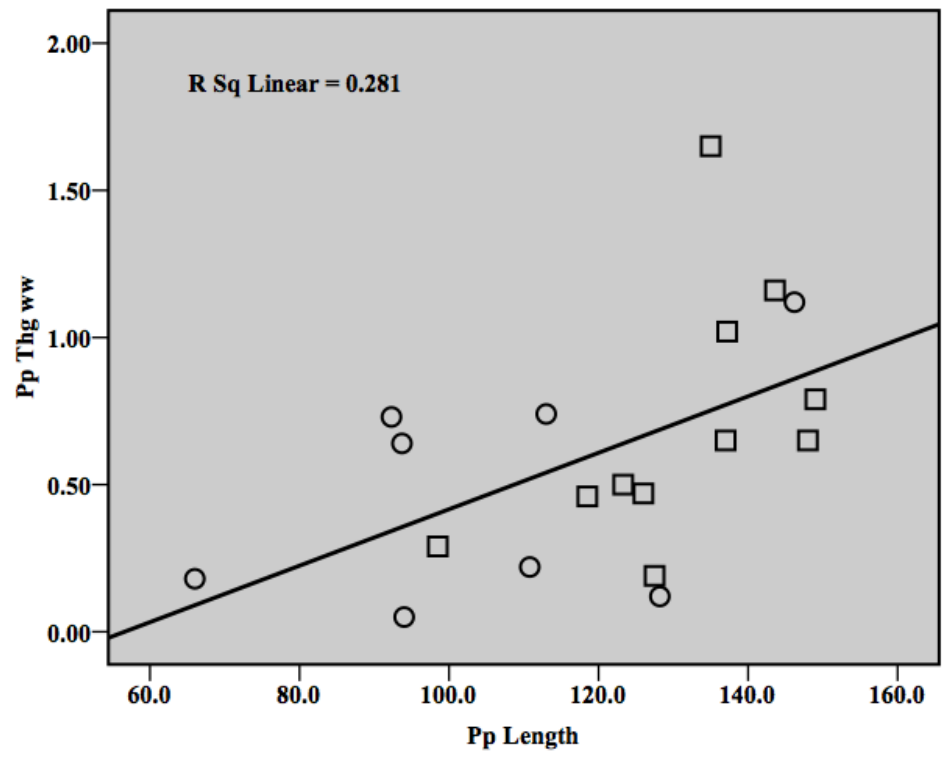


C- Harbor seal

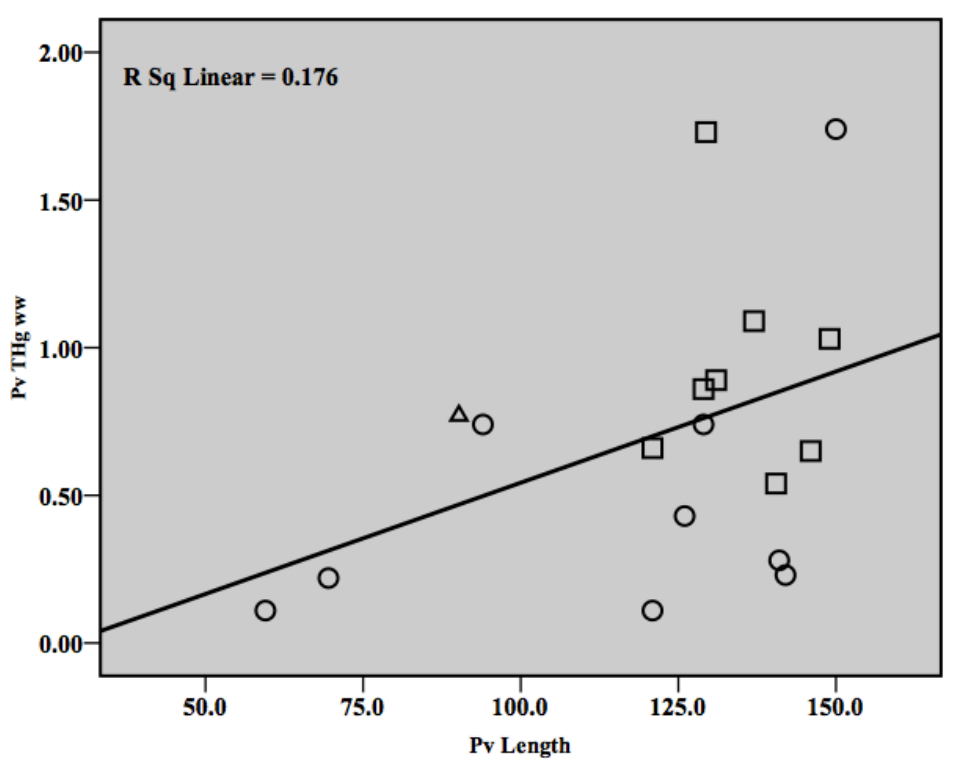

D- Northern elephant seal

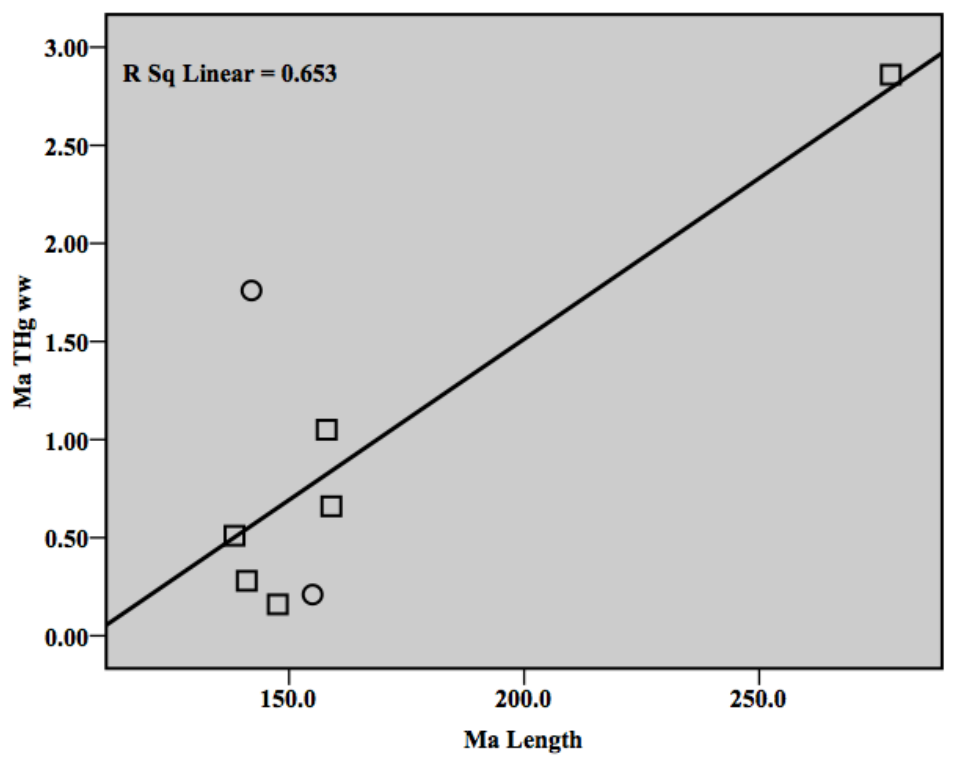


E- Steller sea lion

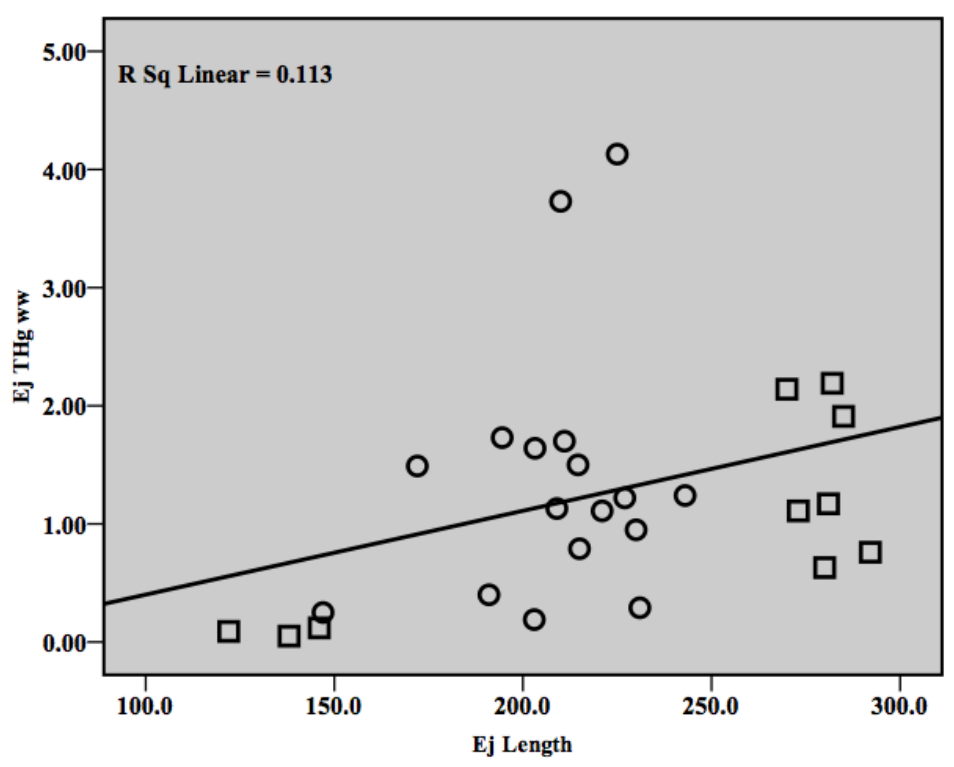




\section{Appendix F}

\section{Tukey HSD Analysis of Health Code vs. [THg]}

Univariate analysis of variance using total mercury concentration (dw) and health codes $1=$ health, $2=$ less health, $3=$ health issues, $4=$ sick, 5 unknown. Based on a significance of 0.05 . The Tukey HSD analysis of variance was used. This analysis was performed to answer any questions that could have come up regarding the health of the individual animal and whether its THg concentration could be significantly correlated. This test compared the health code category against the mean $\mathrm{THg}$ concentration of all animals with that health code to look for a correlation.

\section{Multiple Comparisons}

\begin{tabular}{|c|c|c|c|}
\hline $\begin{array}{l}\text { (I) } \\
\text { Health_Code }\end{array}$ & $\begin{array}{l}\text { (J) } \\
\text { Health_Code }\end{array}$ & $\begin{array}{c}\text { Mean } \\
\text { Difference } \\
(I-J)\end{array}$ & Sig. \\
\hline \multirow[t]{4}{*}{1} & 2 & .0842 & .977 \\
\hline & 3 & -.0821 & .611 \\
\hline & 4 & -.0139 & .999 \\
\hline & 5 & .0342 & .983 \\
\hline \multirow[t]{4}{*}{2} & 1 & -.0842 & .977 \\
\hline & 3 & -.1663 & .803 \\
\hline & 4 & -.0981 & .967 \\
\hline & 5 & -.0500 & .997 \\
\hline \multirow[t]{4}{*}{3} & 1 & .0821 & .611 \\
\hline & 2 & .1663 & .803 \\
\hline & 4 & .0683 & .896 \\
\hline & 5 & .1163 & .563 \\
\hline \multirow[t]{4}{*}{4} & 1 & .0139 & .999 \\
\hline & 2 & .0981 & .967 \\
\hline & 3 & -.0683 & .896 \\
\hline & 5 & .0481 & .975 \\
\hline \multirow[t]{4}{*}{5} & 1 & -.0342 & .983 \\
\hline & 2 & .0500 & .997 \\
\hline & 3 & -.1163 & .563 \\
\hline & 4 & -.0481 & .975 \\
\hline
\end{tabular}




\section{Appendix G}

\section{Step-by-Step Mercury Analysis Procedure}

\section{A. Archiving tissue sample}

1. Muscle tissue should always be collected from the same same area of the animal. I recommend the dorso-lateral region, just posterior to the shoulder blade.

2. Using a stainless steel serrated knife, cut out a piece of muscle approximately 3 " cubed. When in doubt, make the piece larger.

3. Double bag tissue and immediately place on ice for transfer to a -20 degree freezer for storage.

\section{B. Mercury analysis}

1. Everything needs to be very clean. Anything that touches the tissue must be rinsed with diluted $\mathrm{HCl}$ and then further washed with nanopure DI water.

2. Trim the muscle sample to remove all sides that came into contact with air.

3. Cut into fairly small cubes to be blended and homogenized. The homogenization is vital for equal distribution and more accurate results.

4. Blend thoroughly (do not add additional fluids) in a glass walled, stainless steel blade blender.

5. Take two $0.5 \mathrm{~g}$ samples; one for mercury analysis and the other for desiccation.

6. Record everything that is done, especially the exact weight of the tissue that is taken for analysis and desiccation to three decimal places (for example, $0.498 \mathrm{~g}$ )

7. Put one of the samples of the slurry (weight known) into a $10 \mathrm{ml}$ glass ampule, with $1 \mathrm{ml}$ ultra pure nitric acid and $2 \mathrm{ml}$ nanopure DI water.

8. Flame to seal the tip. Go to Step 11.

9. For desiccation take the other sample of slurry (weight known) and put this into a $2 \mathrm{ml}$ cap-less centrifuge tube and weigh it with the tube (muscle and tube weight). This sample is now ready for desiccation. 
10. Put into a vacuum desiccation chamber for a $24 \mathrm{hr}$. cycle. This is plenty of time to completely dry the tissue. It is imperative to record the dried tissuetube weight immediately in order to establish the amount of water lost. Water loss is described as a percent of the original tissue weight.

11. Sealed ampules are autoclaved for 60 min @ 100 degrees centigrade. This acts to digest the tissue. Use caution at all times with high heat and corrosive acids.

12. Prepare the Millennium Merlin Mercury Analyzer for operation. All tubing and glassware should be new and free of cracks, splits, or gaps. The carrier gas needs to be either analytical grade argon or helium. I recommend using argon because this will save glassware from contamination. All gas lines must be sealed with Teflon tape and checked for leaks. The software needs to be up to date and operating flawlessly. The newest version of the software can be downloaded from www.psaanalytical.com.

13. Prepare the stock solution, acid converter solution, and calibration standards. All chemicals have to be mercury free analytical grade, which usually means that it needs to be HPLC grade. The stock solution is a $1 \%$ $\mathrm{HCl}$ mixture of $\mathrm{HCl}$ and nanopure DI water. Make lots of this. The acid converter solution is a mixture of concentrated $\mathrm{HCl}$ solution and tin (II) chloride or stannous chloride. Calibration standards depend on what you expect to find in terms of concentration. I expected to find between 1-10 ppm, so I made five standards of $0.00,1.00,5.00,10.00$, and $20.00 \mathrm{ppm}$. Use a known mercury standard from NIST such as dogfish muscle. Each of the following mentioned solutions have to be made fresh each day to eliminate contamination.

Acid Converter SolutionStock SolutionCalibration Standards-

$$
\begin{aligned}
& 20 \mathrm{~g} \mathrm{SnCl}_{2}+25 \mathrm{ml} \mathrm{HCl}+1 \mathrm{~L} \mathrm{DI} \mathrm{H} \mathrm{H}_{2} \mathrm{O} \\
& 75 \mathrm{ml} \mathrm{HCl}+2.5 \mathrm{~L} \mathrm{DI} \mathrm{H}_{2} \mathrm{O} \\
& 0.00 \mathrm{ppm} \quad 0.00 \mathrm{mg} \mathrm{Hg} \quad 250 \mathrm{ml} \text { Stock Soln } \\
& 1.00 \mathrm{ppm} \quad 0.25 \mathrm{mg} \mathrm{Hg} \quad 250 \mathrm{ml} \text { Stock Soln } \\
& \text { 10.00ppm 2.50mg Hg 250ml Stock Soln }
\end{aligned}
$$

14. After autoclaving samples, break open the top of the ampule and pipet out $1 \mathrm{ml}$ of digested tissue and add to $40 \mathrm{ml}$ of $1 \% \mathrm{HCl}$ solution into a $50 \mathrm{ml}$ centrifuge tube. You should now have $41 \mathrm{ml}$ of a diluted muscle tissue in a $50 \mathrm{ml}$ centrifuge tube.

15. Remember to label everything. 
16. The stannous chloride mixture needs to be bubbled with the carrier gas for one hour prior to analysis. This helps eliminate any water and also mixes the solution.

17. We are now ready to set the operating conditions of the software; how long to run a blank through to clean, how long to cycle through each $41 \mathrm{ml}$ sample, and how long to clear after the sample cycle. My setup was as follows:

Delay- $20 \mathrm{sec}$ Analysis- $60 \mathrm{sec}$ Memory- $80 \mathrm{sec}$. Each sample is cycled twice and averaged. This is beneficial but can also be changed if needed. I recommend testing the functions of the machine and trying a few dry runs to figure out what best would fit your needs.

18. Calibration standards must be run each day to establish a background calibration curve. Warming up the machine up before use is critical. The two peristaltic pumps are connected to the appropriate solutions. The first connection is permanently set in the acid converter solution. The second is only put into the $50 \mathrm{ml}$ centrifuge tube that is filled with the calibration standard. Each standard is run twice and averaged.

19. With each run, it is important to remember to run duplicates, a method blank, and a known spike. For every ten samples, you will need to run one of each. These samples allow you to calculate your reproducibility, percent error, and your method detection limit. When in doubt run two for every ten.

20. Because the tissues for the mercury analysis were diluted, they need to be reconfigured to their original tissue weight. Calculate what was added to the ampules before the analysis $\left(1 \mathrm{ml}\right.$ nitric acid, $2 \mathrm{ml} \mathrm{H}_{2} \mathrm{O}$, and $\left.40 \mathrm{ml} 1 \% \mathrm{HCl}\right)$. For $0.5 \mathrm{~g}$ tissue this equates to a dilution of $86: 1.43 \mathrm{ml}$ of solutions to $0.5 \mathrm{~g}$ tissue. This value will multiply the mercury concentration that was found after analysis. For example, if the concentration from the mercury analyzer read $0.05 \mathrm{ppm}$, you would multiply this by 86 to get your actual $\mathrm{THg}$ concentration before dilution. $86 \times 0.05=4.3 \mathrm{ppm}$. 